\title{
CORROSION TESTING OF CARBON \\ STEEL IN AEREATED GEOTHERMAL BRINE
}

D. F. Sucfu

P. M. Wikoff

Published February 1981

EG\&G Idaho, Inc. Idaho Falls, Idaho 83415

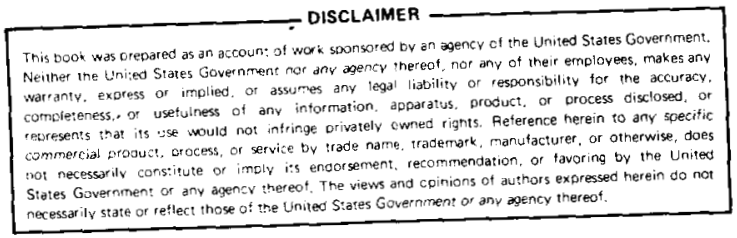




\section{DISCLAIMER}

This report was prepared as an account of work sponsored by an agency of the United States Government. Neither the United States Government nor any agency Thereof, nor any of their employees, makes any warranty, express or implied, or assumes any legal liability or responsibility for the accuracy, completeness, or usefulness of any information, apparatus, product, or process disclosed, or represents that its use would not infringe privately owned rights. Reference herein to any specific commercial product, process, or service by trade name, trademark, manufacturer, or otherwise does not necessarily constitute or imply its endorsement, recommendation, or favoring by the United States Government or any agency thereof. The views and opinions of authors expressed herein do not necessarily state or reflect those of the United States Government or any agency thereof. 


\section{DISCLAIMER}

Portions of this document may be illegible in electronic image products. Images are produced from the best available original document. 
A special thanks is extended to J. F. Whitbeck for his continued support and contributions to this work. The assistance of G. L. Mines and A. D. Crandall in the system design is gratefully acknowledged. The excellent work of $L$. Udy and S. J. Ward of the Raft River geothermal test facility is to be highly commended. It was due to their tireless effort that a large amount of testing was performed in a relatively short time.

\section{DISCLAIMER}

Reference to a company or product by name does not imply approval or recommendation of the product by the U.S. Department of Energy or EG\&G Idaho, Inc. to the exclusion of others that may have the same properties. 


\begin{abstract}
Two major problems are associated with the use of cooled geothermal water as coolant for the 5 MW(e) Pilot Power Plant at Raft River. They are: (1) a scaling potential owing to the chemical species present in solution, and (2) the corrosive nature of the geothermal water on carbon steel. A water treatment test program was established to reduce or eliminate these problems. Data show that scale can be prevented by a combination of dispersants and controlling the concentration of scaling species in the circulating water. Corrosion cannot be controlled without a pretreatment of tubing material. With the pretreatment, a protective gamma iron oxide film is laid down on the tube surface, that with proper corrosion inhibitor additives, significantly reduces both general and pitting corrosion. However, longer term testing is required to determine protection of pitting corrosion.
\end{abstract}




\section{SUMMARY}

The Raft River $5 \mathrm{MW}(\mathrm{e})$ Pilot Power Plant will use cooled geothermal water as make-up for the evaporative cooling tower. This water is high in chloride concentration and represents a very corrosive environment for the carbon steel tube material in the isobutane condenser. The experiments reported here were designed to provide a water treatment program for scale prevention and corrosion protection of the isobutane condenser.

The water treatment program consisted of three types of tests. The first test was a series of cleaning and passivating experiments to define chemical requirements and a procedure for cleaning and passivating the isobutane condenser. The second set of tests were spinner tests used to screen the effect of a a variety of chemicals on corrosion reduction. The third series of tests used the pilot cooling tower test units which evaluated the total chemical treatment program.

Resul ts show that the isobutane condenser has been cleaned of oil, and scale and that protective gamma iron oxide film has been effectively laid down. Data show that a chromate, phosphate, and zinc inhibitor program could control both general and pitting corrosion, within the 90-day test period. However, due to environmental concerns the use of chromate was eliminated as a corrosion inhibitor. Data from subsequent tests of a polyphosphate zinc treatment indicate that pitting corrosion has been significantly reduced. Data also shows that scale formation is eliminated by use of dispersants and controlling the concentration of scaling species in the circulating system.

The water treatment for the $5 \mathrm{MW}$ consists of three separate units. The make up water is treated in the softener to remove scaling species followed by $\mathrm{pH}$ adjustment to prevent filter plugging. The recirculating water is treated with chemical additives to prevent corrosion and scale deposition, and blowdown is treated for removal of heavy metals to meet environmental regulations and phosphate to prevent plugging of reinjection wells. 
Based on the above testing program, the chemical requirements for the different components of the water treatment system are:

1. Warm Lime Softener

A. Magnesium chloride - for silica removal, estimated feed rate is $3.81 \mathrm{~b} / 1000 \mathrm{gal}$ make-up (455 ppm)

B. Lime - for $\mathrm{pH}$ control, estimated feed rate is $2.71 \mathrm{~b} / 1000$ gal make-up (320 ppm)

C. Soda ash - for calcium removal, estimated feed rate is 1.9 1b/1000 gal make-up (230 ppm)

D. Polyelectrolyte - to aid in settling, estimated feed rate is $0.02 \mathrm{lb} / 1000 \mathrm{ga} 1$ make-up (2 ppm)

E. Sulfuric Acid - post acidification to prevent plugging of sand/anthracite filters, estimated feed rate is $2.51 \mathrm{~b} / 1000$ gal make-up (300 ppm)

The effluent water quality from the softener should be

a. ${ }^{2}$ Silica $-4-5 \mathrm{ppm}$ as $\mathrm{SiO}_{2}$

b. ${ }^{\text {a }}$ Hardness total $-20-30$ ppm as $\mathrm{CaCO}_{3}$

c. The $\mathrm{pH}$ in the softener must be maintained at a minimum of 10.2

d. The $\mathrm{pH}$ of water going to filters should be 7.1-7.6

a. The Silica and hardness concentrations will be monitored continuously with continuous flow analyzers located in the makeup stream to the cooling tower basin. 


\section{Cooling Water Treatment}

The chemical additives and control levels for the cooling water are:

A. ${ }^{\text {a }}$ Phosphate - corrosion inhibitor, estimated feed rate is $0.95 \mathrm{lb} / 1000 \mathrm{gal}$ of blowdown. Control level will be $40 \mathrm{ppm} \pm 5 \mathrm{ppm}$ total phosphate.

B. Zinc Sulphate - corrosion inhibitor, estimated feed rate is 0.1 1b/1000 gal blowdown (3 ppm)

C. Betz 562-C- copper corrosion inhibitor, estimated feed rate is $0.83 \mathrm{lb} / 1000 \mathrm{gal}$ blowdown (100 ppm)

D. Betz 2020 - dispersant, estimated feed rate is $1.3 \mathrm{lb} / 1000 \mathrm{gal}$ blowdown (150 ppm)

E. Betz 426 - dispersant, estimated feed rate is $0.83 \mathrm{lb} / 1000$ gal blowdown (100 ppm)

F. Betz C-30 and 508 - biological and slime control, to be shot fed one half pint twice weekly.

G. PH range $-6.8-7.4$

a. A continuous flow analyzer located in the cooling water circulating line will continuously monitor the phosphate levels. 
3. Bl owdown Treatment

The chemical requirements to remove phosphate and heavy metals prior to reinjection are:

A. Ferrous Sulfate - for phosphate removal, the estimated feed rate is $1.71 \mathrm{~b} / 1000 \mathrm{gal}$ blowdown (28 ppm iron)

B. Lime - for $\mathrm{pH}$ adjustment to precipitate metals and phosphate, estimated feed rate is $1.21 \mathrm{~b} / 1000 \mathrm{gal}$ blowdown (150 ppm)

C. Polyelectrolyte - to aid in settling, estimated feed rate is 0.02 1b/1000 gal blowdown (2 ppm)

The chemical requirements stated above have been gathered from various water treatment pilot scale test equipment located at Raft River. These units may not be as efficient as the $5 \mathrm{MW}(\mathrm{e})$ equipment, al so test conditions were more severe than conditions anticipated in the $5 \mathrm{MW}(\mathrm{e})$ in normal operation. It is therefore, possible that when the plant is operating, feed rates may be lowered, hence reducing costs while maintaining chemical efficiency. However, during start-up and initial operation, the above requirements should be adhered to; as they have proven effective and will avert any premature shutdown or component failure. 
ACKNOWLEDGEMENTS $\ldots \ldots \ldots \ldots \ldots \ldots \ldots \ldots \ldots \ldots \ldots \ldots \ldots \ldots \ldots \ldots \ldots \ldots$

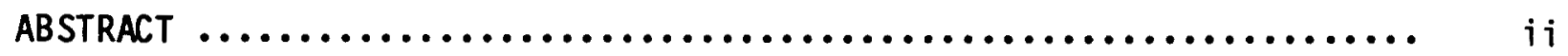

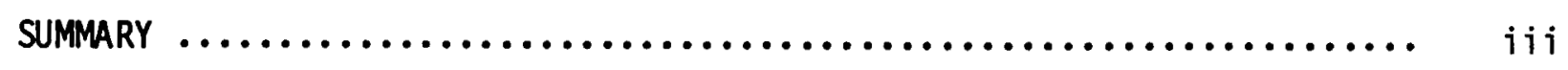

1. INTRODUCTION $\ldots \ldots \ldots \ldots \ldots \ldots \ldots \ldots \ldots \ldots \ldots \ldots \ldots \ldots \ldots \ldots \ldots \ldots \ldots \ldots \ldots$

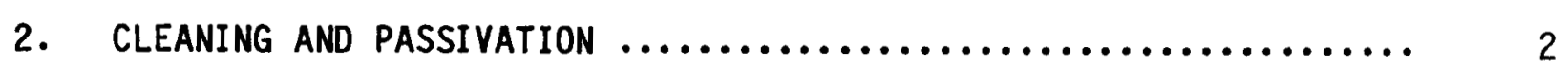

2.1 Test Procedure $\ldots \ldots \ldots \ldots \ldots \ldots \ldots \ldots \ldots \ldots \ldots \ldots \ldots \ldots \ldots$

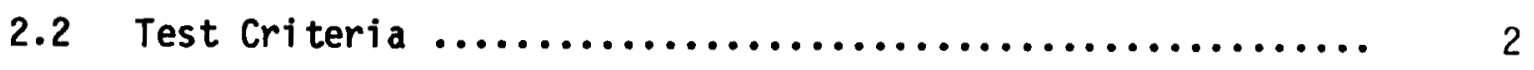

2.3 Test Results $\ldots \ldots \ldots \ldots \ldots \ldots \ldots \ldots \ldots \ldots \ldots \ldots \ldots \ldots \ldots \ldots \ldots$

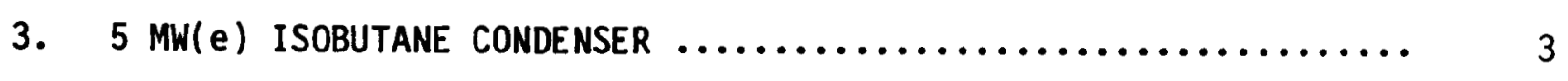

3.1 Condenser Cleaning and Results $\ldots \ldots \ldots \ldots \ldots \ldots \ldots \ldots \ldots \ldots$

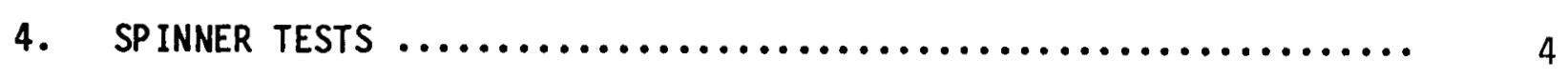

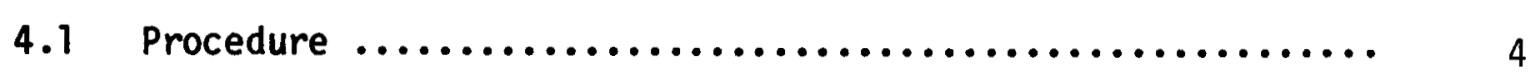

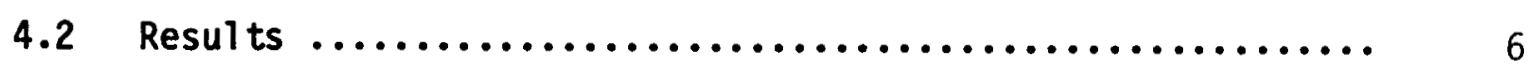

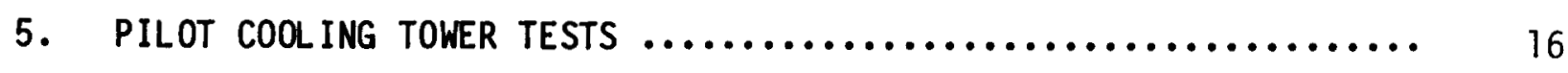

5.1 Pilot Cooling Tower Test Units $\ldots \ldots \ldots \ldots \ldots \ldots \ldots \ldots \ldots \ldots$

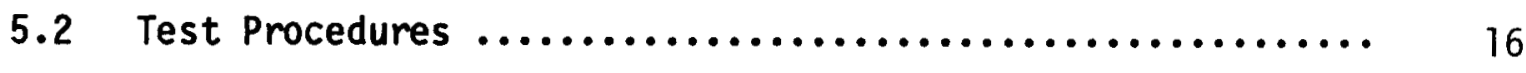

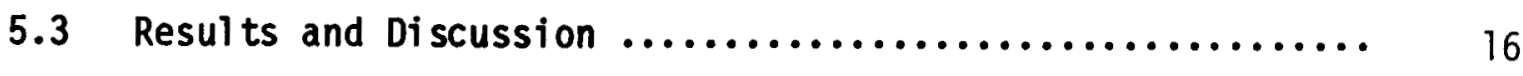

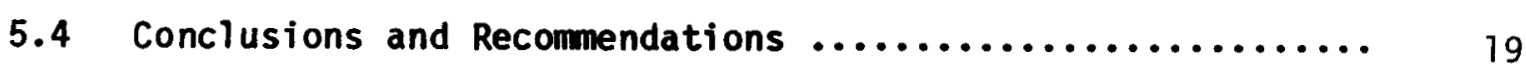

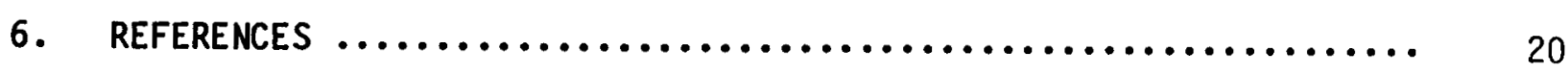

APPENDIX A--CLEANING AND FILMING TESTS $\ldots \ldots \ldots \ldots \ldots \ldots \ldots \ldots \ldots \ldots \ldots \ldots$

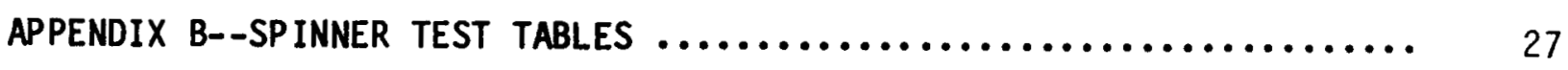

APPENDIX $C$--PILOT COQ ING TOWER TEST TABLES $\ldots \ldots \ldots \ldots \ldots \ldots \ldots \ldots \ldots \ldots$ 
Figure 1--Spinner Test Apparatus $\ldots \ldots \ldots \ldots \ldots \ldots \ldots \ldots \ldots \ldots \ldots \ldots$

Figure 2--Pit Depth Versus Time With Different Corrosion Inhibitor Systems at 1,000 ppm Chloride

Figure 3--Weight Loss Versus Time With Different Corrosion Inhibitor Systems at 5,000 ppm $\mathrm{Chl}$ oride

Figure 4--Pit Depth Versus Time With Different Corrosion Inhibitors at $5,000 \mathrm{ppm}$ Chloride

Figure 5--Weight Loss Versus Chloride Concentration With a Phosphate

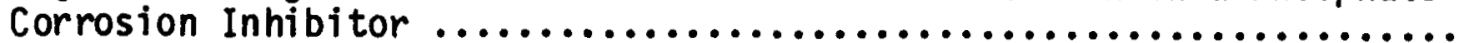

Figure 6--Pit Depth Versus Chloride Concentration With a Chrome,

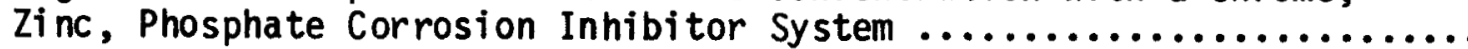

Figure 7--Pit Depth Versus Chloride Concentration With a Phosphate Corrosion Inhibitor

Figure 8--Weight Loss Versus Chromate Concentration at 10,000 ppm Chioride

Figure 9--Pilot Cooling Tower Test Unit 


\section{INTRODUCTION}

The Raft River 5 MW(e) Pilot Power Plant is located in a region where neither ground nor near-surface aquifer water is available for make-up to the plant's evaporative cooling tower. Therefore, the plant will use cooled geothermal water, discharging from the power plant, as coolant to circulate between the condenser and the wet (open-loop, evaporative) cooling tower. This application requires that (1) silica be removed by means of a pretreatment process, and (2) the recirculating water be subsequently treated with biocides, antiscalants, and corrosion inhibitors to protect the carbon steel isobutane condenser.

The $5 \mathrm{MW}(\mathrm{e})$ isobutane condenser consists of 7260 tubes $12.19 \times 0.019 \mathrm{~m}$ (40 ft $\times 3 / 4 \mathrm{in.})$. The tube wall thickness is $2.2 \mathrm{~mm}(0.085 \mathrm{in}$.) with a designed isobutane pressure tolerance of $0.86 \mathrm{~mm}(0.34 \mathrm{in.})$ wall thickness. The wall thickness was assumed adequate to account for metal loss due to corrosion. However, Suciu and Miller ${ }^{1}$ (pilot test), during short term pilot cooling tower tests, found that corrosion protection with the recommended chromate-zinc treatment was inadequate. A statistical analysis of this data by the Radian Corporation ${ }^{2}$ indicated an expected isobutane condenser 1 ifetime of 11 to 16 weeks.

A water treatment program was then established to define a corrosion treatment system that would extend the expected life of the isobutane condenser. The program was conducted by EG\&G (Conversion Technology Branch) in cooperation with Paul Puckorius (Water Treatment consultant, Puckorius \& Associates) and the Radian Corporation (metal failure analysis specialists). The tests performed at Raft River used the spinner test apparatus, pilot cooling test towers and selected equipment from the $60 \mathrm{~kW}$ prototype power plant water treatment system.

The 5 MW(e) isobutane condenser was inspected in May 1980 and was found to be covered with oil, scale and corrosion products. This required that the condenser be cleaned prior to plant start up.

The specific objectives of the $5 \mathrm{MW}(\mathrm{e})$ water treatment program were to: 
1. Define a chemical cleaning and passivating procedure for the $5 \mathrm{MW}(\mathrm{e})$ isobutane condenser,

2. Determine type and concentration of dispersants required to prevent scale deposition on the heat exchanger surface,

3. Determine corrosion inhibitors required to prevent corrosion, particularly pitting corrosion of the carbon steel tube material.

\section{CLEANING AND PASSIVATION}

\subsection{Test Procedure}

An experimental test loop was set up to simulate temperature and velocity conditions expected in cleaning and passivating the isobutane condenser. The test loop consisted of a nineteen litre container, heating coils, a model P-7 Eastern pump and $0.39 \mathrm{~m}$ by $0.019 \mathrm{~m}$ ASTM A-179 carbon steel tubes. Solutions of various chemical reagents, maintained at a temperature of $333 \mathrm{~K}\left(60^{\circ} \mathrm{C}\right)$ were pumped through the tube samples at a velocity of approximately $0.27 \mathrm{~m} / \mathrm{s}(0.9 \mathrm{ft} / \mathrm{s})$ for periods of 2 to 8 hours. Tube samples were then removed, dried and sent to Radian for examination. Raft River domestic water used for these tests has a conductivity of $2100 \mu \mathrm{mho} / \mathrm{cm}$ and a chloride concentration of $400 \mathrm{ppm}$.

\subsection{Test Criteria}

Prior to testing, the following criteria were established to define a successful program:

1. The tube surface be free from oil and grease,

2. The tube surface be clean and free from all scale deposits, 
3. The protective gamma iron oxide film was formed on the tube surface and was continuous.

\subsection{Test Results}

The chemicals used and their concentrations are listed in Appendix $A$, Table 1A. These tests resulted in a three step program, based on test number 32 in Table $1 A$ and consists of:

1. A degreasing step of $5 \mathrm{w} / 0$ caustic, $1 \mathrm{w} / 0 \mathrm{TSP}$ (trisodium phosphate) and a surfactant to remove grease and oil,

2. A cleaning step of a double inhibited phosphoric acid solution at $\mathrm{pH} 2.5$ to remove scale and corrosion products,

3. A filming step of 3 w/o NALPREP 331 to form the protective gamma iron oxide film.

The industrial vendor later recormended a $21 \mathrm{w} / 0$ phosphoric acid solution rather than the $\mathrm{pH} 2.5$ solution. This was tested in the $1 \mathrm{ab}$ and subsequently incorporated as Step 2 in the cleaning procedure.

\section{3. $5 \mathrm{MW}(\mathrm{e})$ ISOBUTANE CONDENSER}

Based on the preliminary laboratory tests, a chemical treatment was specified (2.3) and an industrial vendor selected for the operation.

\subsection{Condensor Cleaning and Results}

The isobutane condenser was cleaned and passivated by Western Industrial from July 14, 1980 until July 21, 1980. Inspection after acidizing showed the condensor has been cleaned of rust, scale and oil. Inspection after passivation showed a predominately rusty condition on all tubes and the water box. 
Operational procedures were reviewed and the cleaning and passivation steps repeated during the period of July 23 through July 27, 1980. The condenser was inspected August 5, 1980 with much better results. Most of the condenser tubes showed excellent passivation; however, spotty results existed, particularly in the top six rows of tubes and on the heads and tube sheet. Some rust spots of similar appearance in the water box and on the tube sheet showed a good film beneath the rust. The lack of passivation in the top tubes was probably due to poor flow distribution or a small air pocket which prevented consistent exposure to the passivating solution. Rather than attempt another passivation the condenser was placed in wet layup with the passivating solution. In October the passivating solution was circulated through the condenser for one week and drained. An inspection showed that the rust spots noticed in August were gone and the condenser was in an excellent stage of passivation. The condenser was then dried and laid up under a 2 to 5 psi nitrogen purge.

\section{SPINNER TESTS}

The spinner, tests were a series of short term corrosion tests conducted to determine the effects of chloride concentration, chromate concentration, various chemical treatments and $\mathrm{pH}$ on the corrosion of 10 w carbon steel coupons.

\subsection{Procedure}

The apparatus for the spinner test is shown in Figure 1 . Four coupons, $(75 \times 13 \times 3 \mathrm{~mm}(3 \times 1 / 2 \times 1 / 8 \mathrm{in}$. $))$ were placed on a $15.2 \mathrm{~cm}$ disk and rotated at $200 \mathrm{rpm}(21 \mathrm{rad} / \mathrm{s})$ in 221 iters of treated Raft Rivera geothermal water, unless otherwise designated. Each 26 liter glass jar was fitted with four $2.5 \mathrm{~cm}$ baffles to eliminate the vortexing created by stirring at $200 \mathrm{rpm}$. The system was aerated and maintained at a temperature

a. Treated Raft River geothermal water has been chemically treated for silica and hardness reduction. 


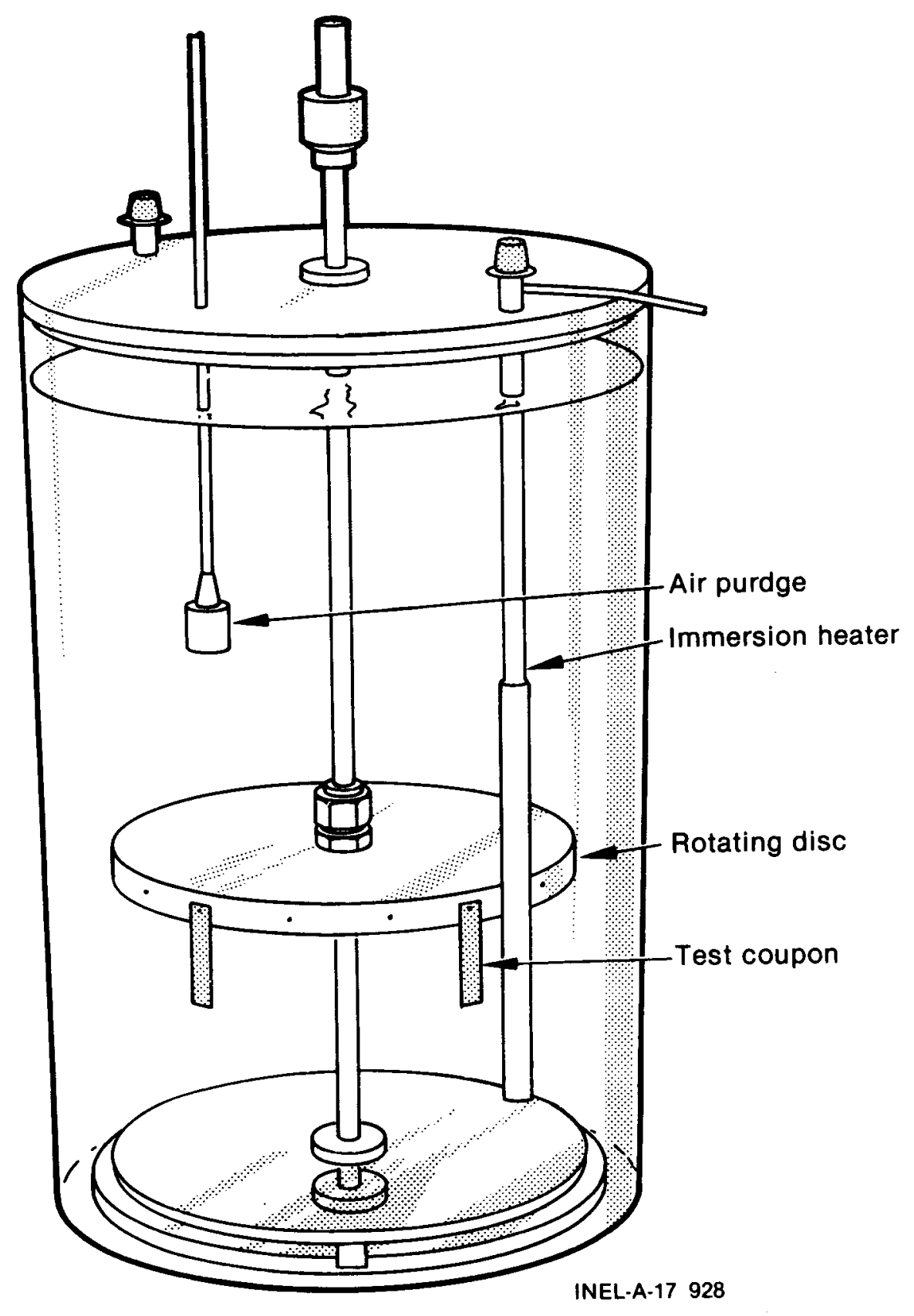

Figure 1: Spinner Test Apparatus 
of $308 \mathrm{~K}\left(35^{\circ} \mathrm{C}\right)$. The $\mathrm{pH}$ was maintained by the addition of dilute sulfuric acid or sodium hydroxide. To each test dispersants were added for scale prevention. Each test duration was approximately one week with seven coupons being prepared, as described below, for each test.

Coupons were removed and added according to a planned interval test schedule. 3 This is a schedule which allows one to determine whether the change in corrosion rate is due to a change in the corrosivity of the fluid or to a change in the corrodibility of the metal.

Prior to corrosion testing the coupons were degreased with 5 w/o caustic solution and cleaned with a $21 \mathrm{w} / 0$ inhibited phosphoric acid solution prior to weighing. After weighing the coupons were prefilmed at approximately $0.15 \mathrm{~m} / \mathrm{s}(0.5 \mathrm{ft} / \mathrm{s})$ and $323 \mathrm{~K}\left(50^{\circ} \mathrm{C}\right)$ in 101 iters of Raft River domestic water with $3 \mathrm{w} / 0$ Nalco 331 polyphosphate solution for approximately 16 to 22 hours.

Following exposure the coupons were air dried, examined and cleaned by soaking in a $20 \mathrm{v} / 0$ solution of hydrochloric acid for 30 minutes and scrubbing under running water. The coupons were dried and weighed. The coupons were examined at $20 \times$ magnification for pit formation and depth.

\subsection{Test Results}

Prefilming causes, in general, more weight loss than the following week exposure. The weight loss is due to dissolution of loose metal during acidizing and dissolution of iron at the surface to form an iron oxide film. Since the weight loss is dependent on duration of prefilming, comparison of weight loss between test series is difficult. However, four spinners were set up such that they had the same prefilming time so comparison within a series is possible. In addition, comparison of pit depths among series is possible. All weight loss data reported includes the weight loss due to the prefilming. 
Corrosion of low carbon steel was examined as a function of:

1. Exposure to Raft River domestic or treated geothermal with and wi thout prefilming (Table 1B),

2. Inhibitor systems in INEL tap water at $1000 \mathrm{ppm}$ chloride, ( Table 2B)

3. Inhibitor systems in treated geothermal water at $5000 \mathrm{ppm}$ chloride (Table 3B)

4. Corrosion versus chloride concentration (Tables $4 B$ and $5 B$ )

5. Corrosion versus chromate concentration (Table 6B)

6. Corrosion versus $\mathrm{pH}$ of the system (Table 7B).

The general results are summarized below:

1. Wi thout the addition of corrosion inhibitors, corrosion of carbon steel is catastrophic in either domestic or treated geothermal water inspite of prefilming. (Table IB)

2. Of the corrosion inhibition systems compared, zinc-chromate or chromate-phosphate decreases the general corrosion; however, the tests indicate zinc is necessary to decrease pitting. (Figures 2, 3 and 4, Table 2B and 3B)

3. General corrosion is proportional to the chloride concentration, the 1 imit being dependent on the corrosion treatment. The pit depth appears to be directly proportional to increase in chloride concentration. (Figures 5, 6 and 7, Tables 4B and 5B) 


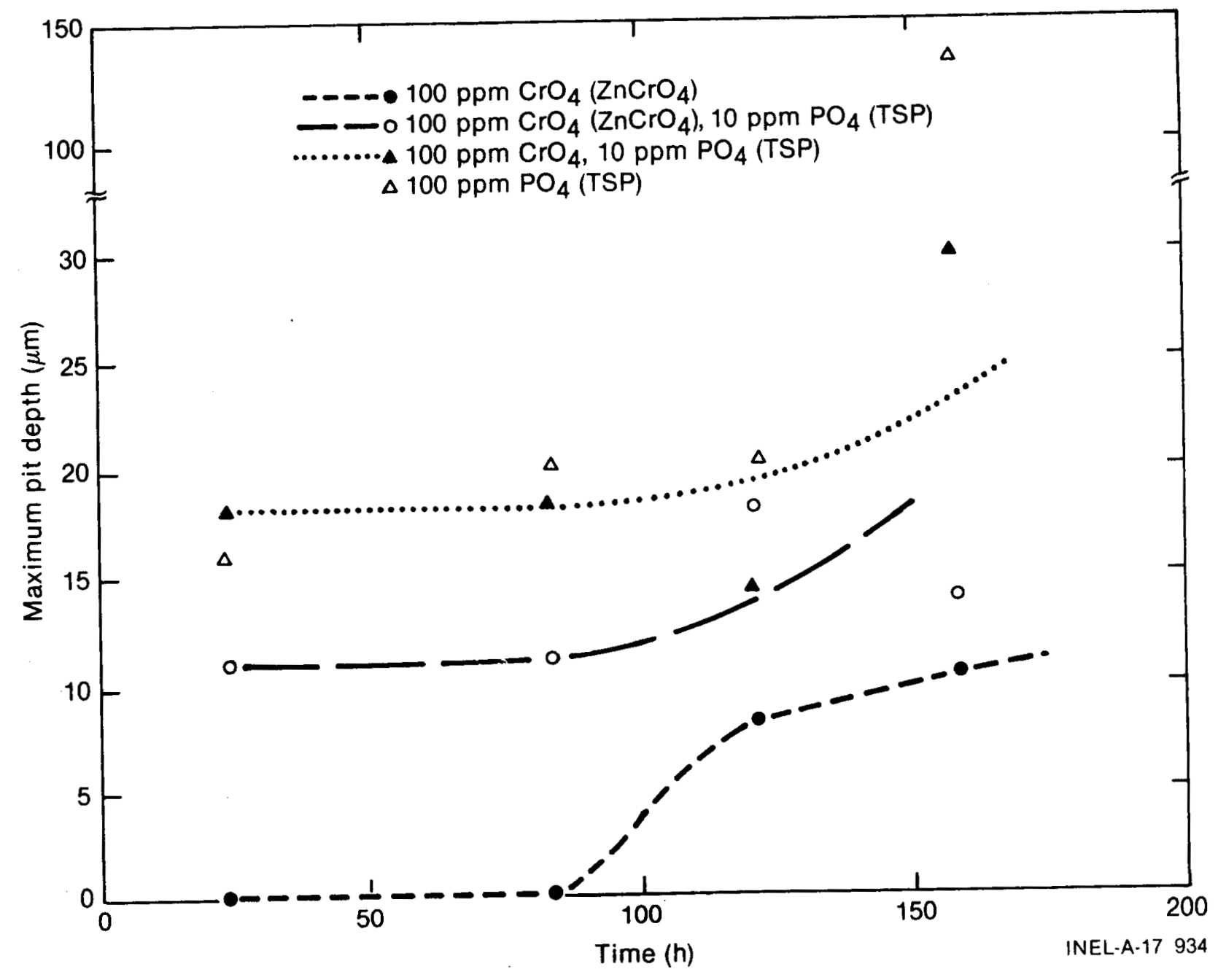

Figure 2: Pit Depth Versus Time with Different Corrosion Inhibitor Systems at 1,000 ppm Chloride 


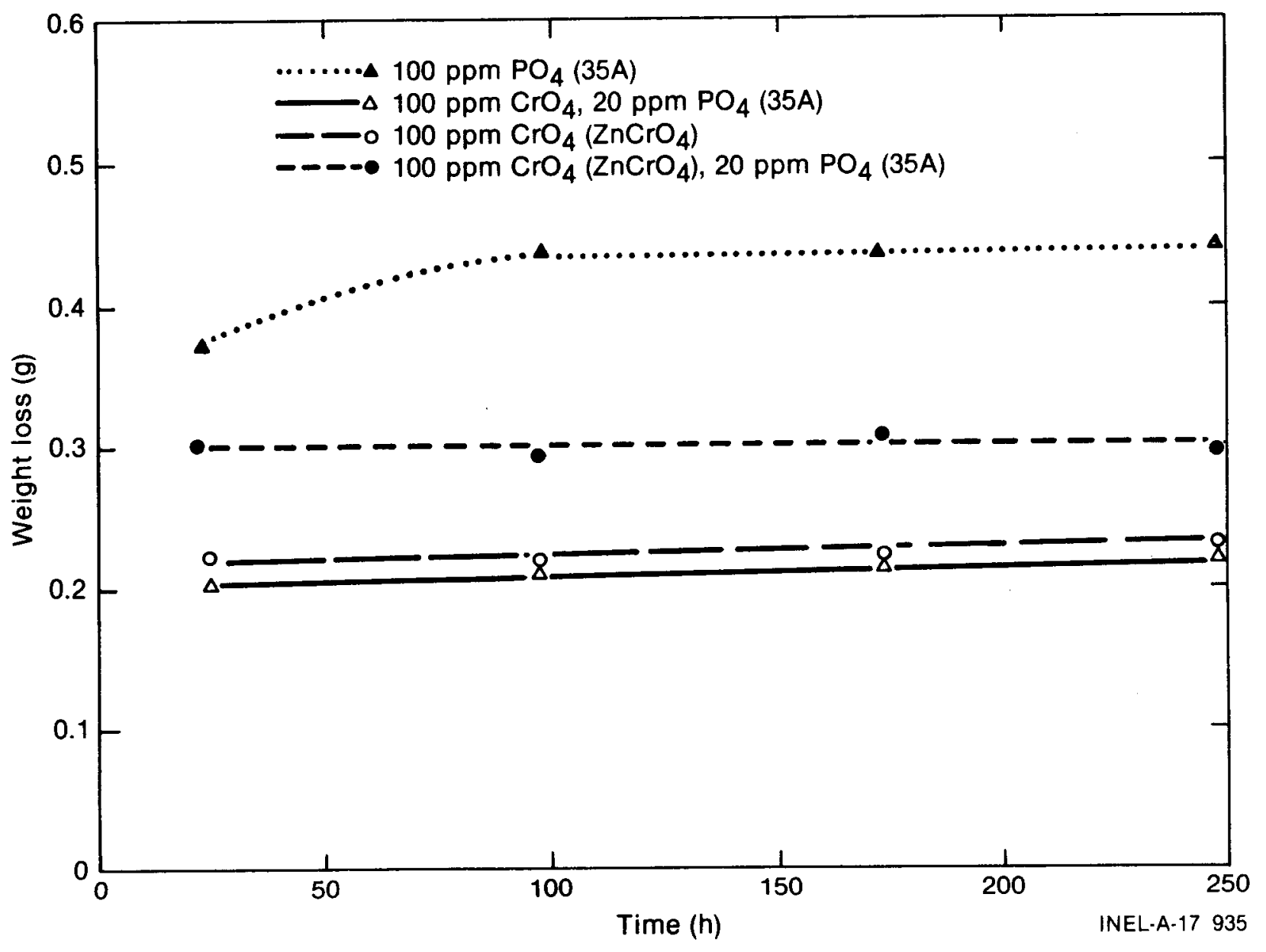

Figure 3: Weight Loss Versus Time with Different Corrosion Inhibitor Systems at 5,000 ppm Chloride 


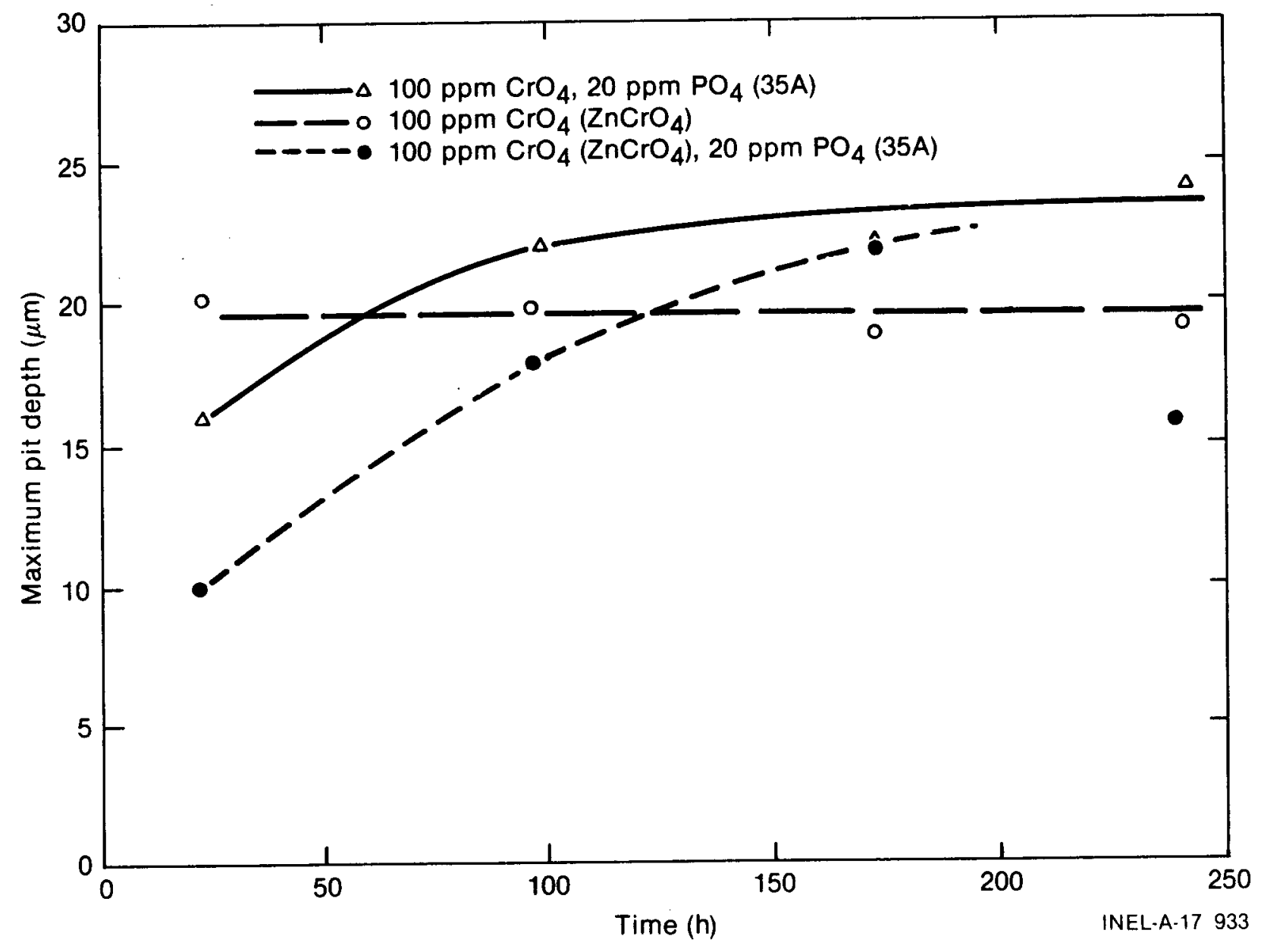

Figure 4: Pit Depth Versus Time with Different Corrosion Inhibitors at 5,000 ppm Chloride 


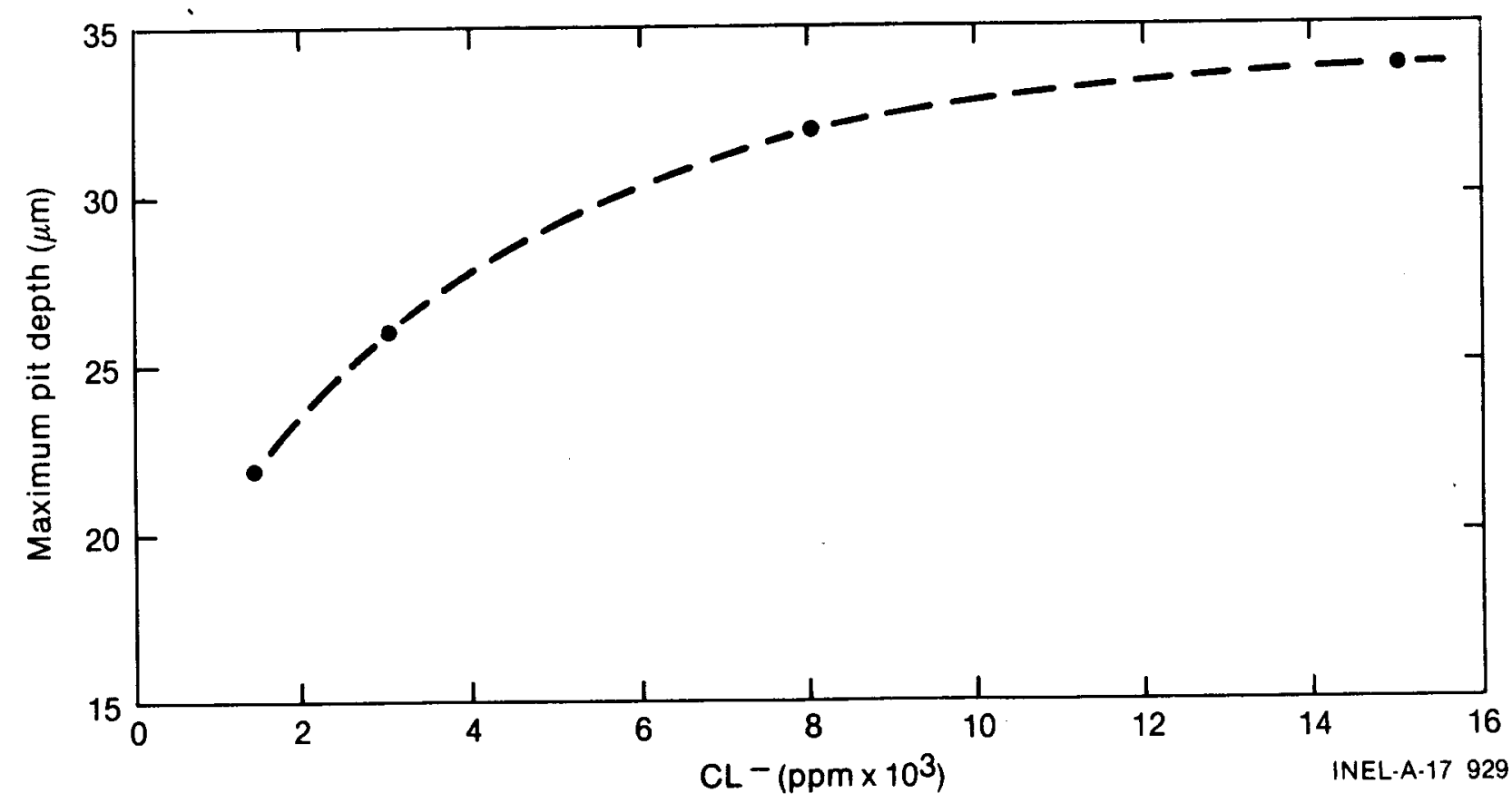

Figure 5: Weight Loss Versus Chloride Concentration with a Phosphate Corrosion Inhibitor 


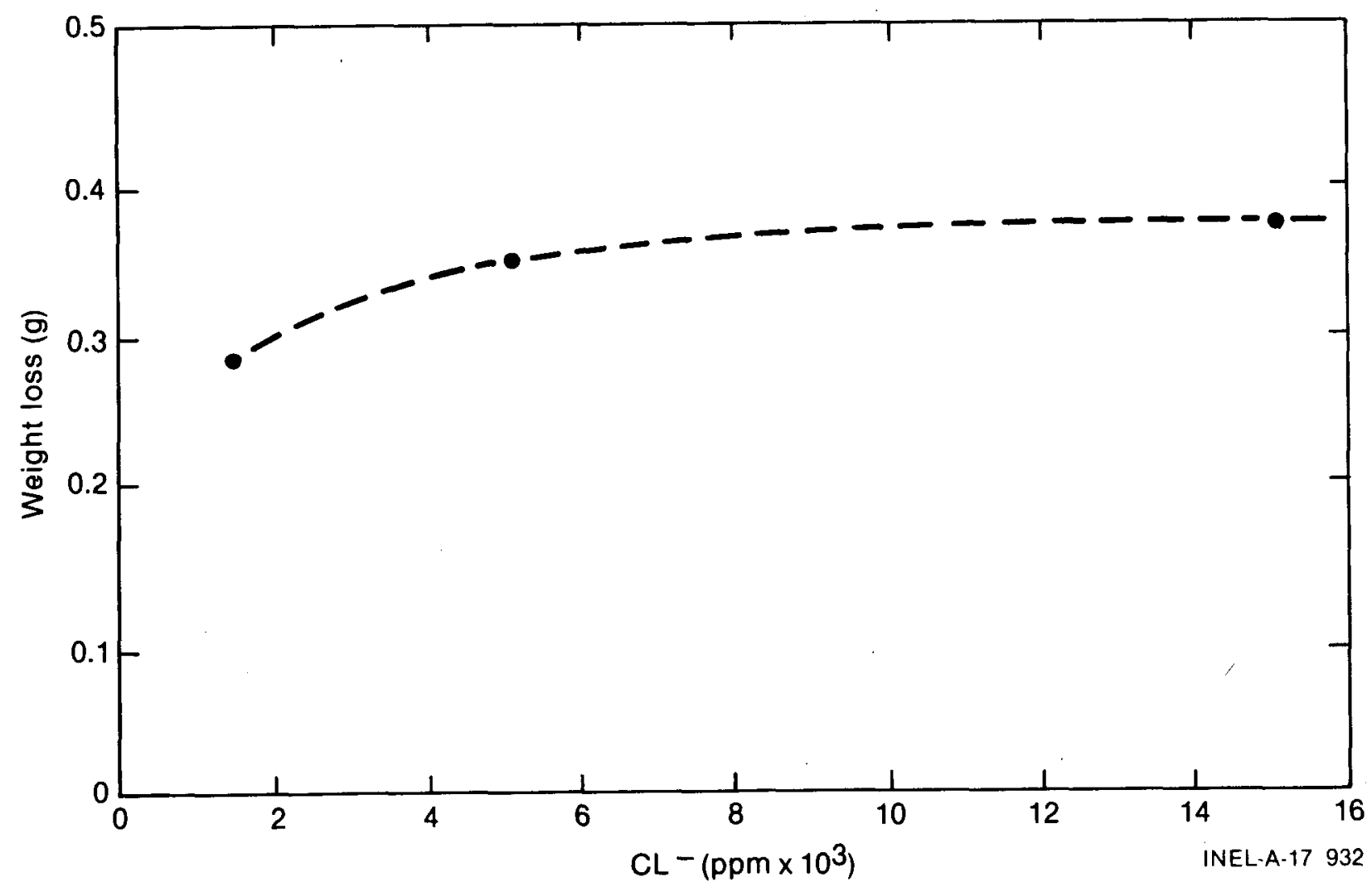

Figure 6: Pit Depth Versus Chloride Concentration with a Chrome, Zinc, Phosphate Corrosion Inhibitor System 


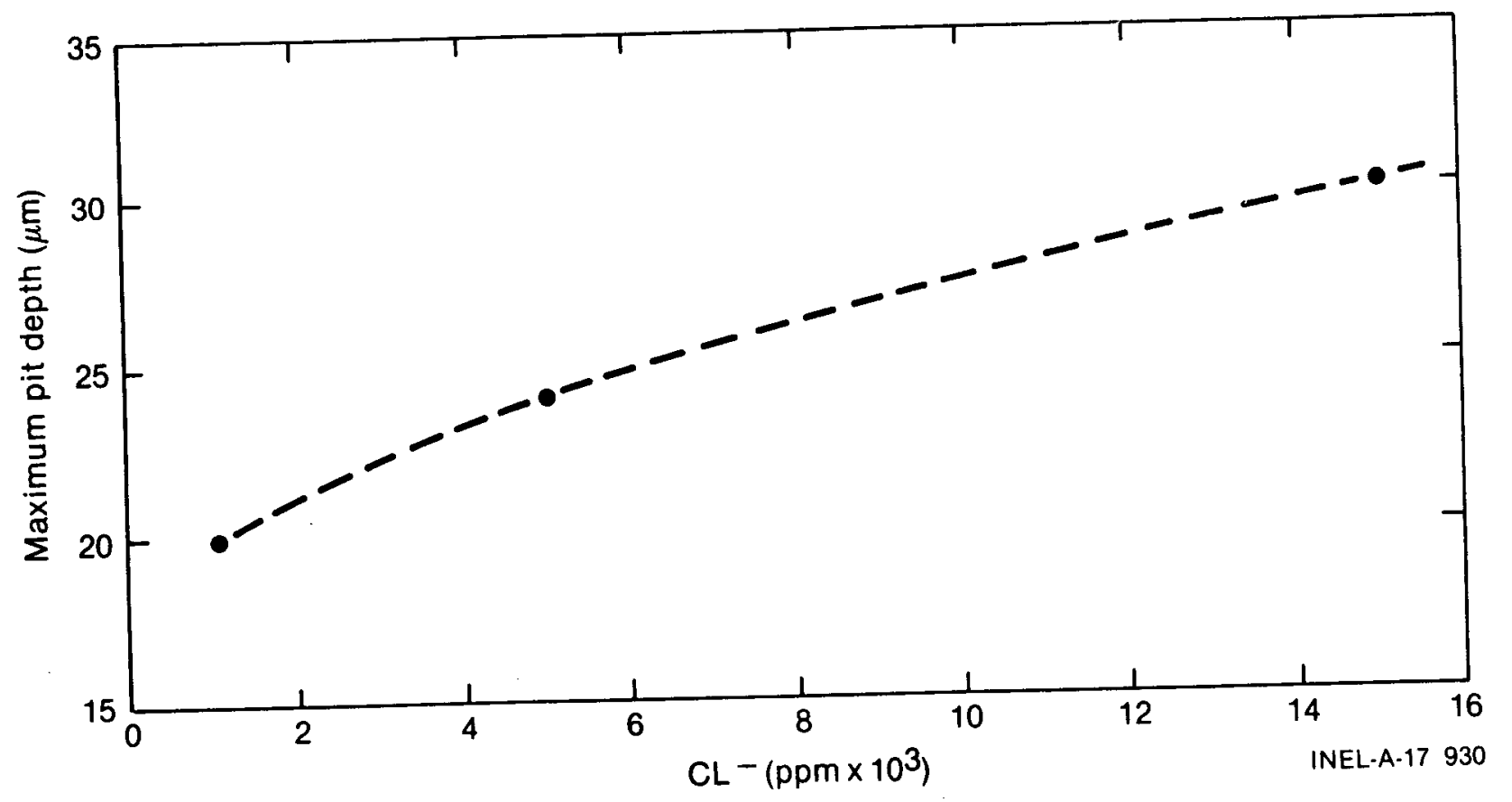

Figure 7: Pit Depth Versus Chloride Concentration with a Phosphate Corrosion Inhibitor 
4. There appears to be a concentration range at which chromate in conjunction with zinc and phosphate is an effective inhibitor and is not detrimental. (Figure 8 , Table 6B)

5. Increasing the $\mathrm{pH}$ from 6.5 to 7.5 decreased the general corrosion. (Table 7B)

To establish a base for the future tests, the corrosion of filmed and unfilmed carbon steel coupons were examined in domestic and in treated geothermal water without the addition of corrosion inhibitors. The results of these tests were as anticipated. Corrosion is less severe in domestic water than treated geothermal for both the prefilmed and unfilmed coupons; prefilming, however, reduced the amount of general corrosion. In all cases the coupons were so severely corroded that none of the original surface remained for pit depth measurement. 


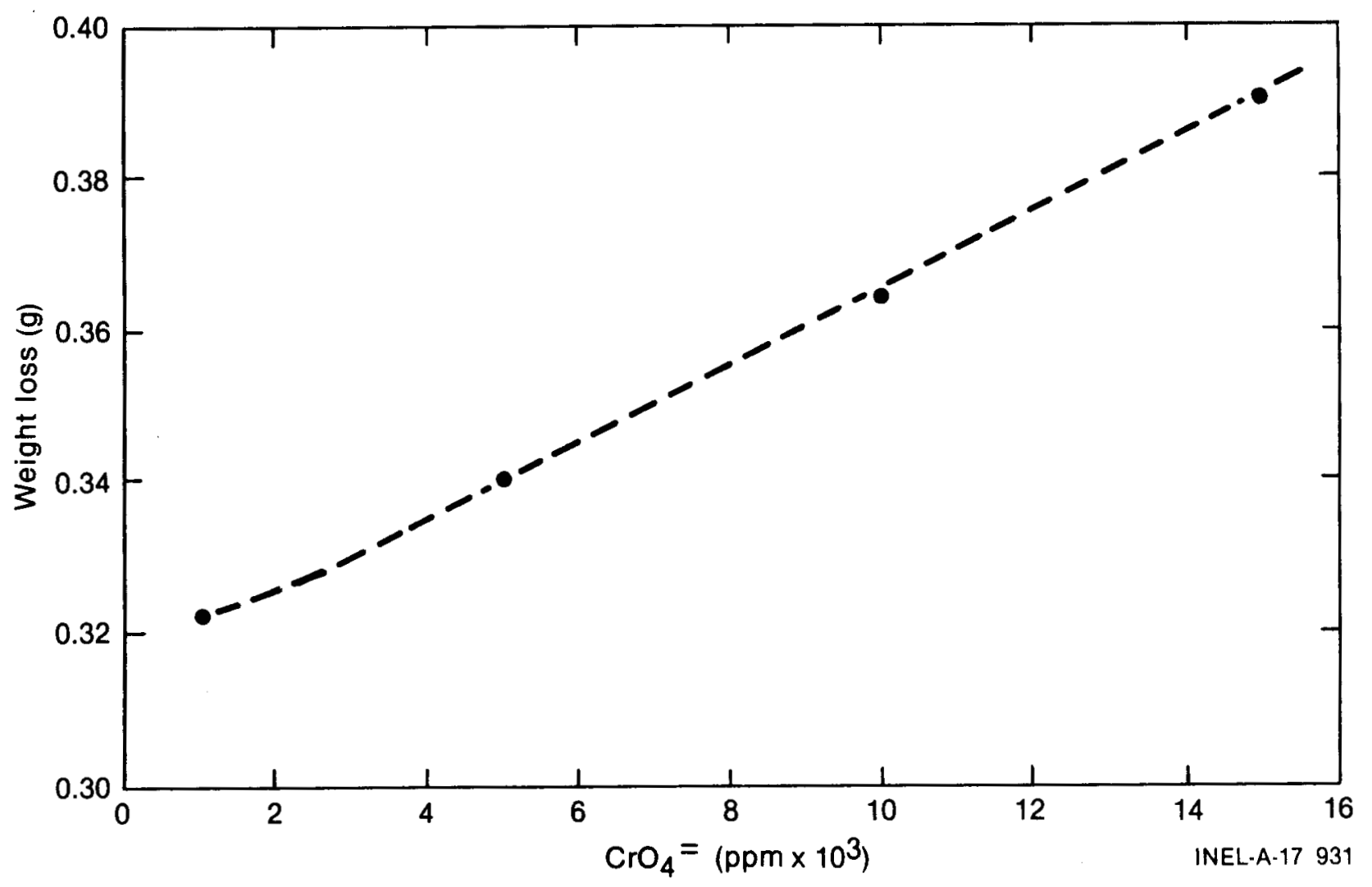

Figure 8: Weight Loss Versus Chromate Concentration at 10,000 ppm Chloride 


\section{PILOT COOLING TOWER TESTS}

\subsection{Pilot Cooling Tower Test Units}

The pilot cooling tower test units, figure 9, were designed to simulate operating conditions found in geothermal evaporative cooling heat rejection systems. The cooling water circulation rate is controlled at $1.5 \mathrm{~m} / \mathrm{s}(5 \mathrm{ft} / \mathrm{sec})$ on the shell side of a tube and shell heat exchanger. The heat load to the cooling water is from geothermal water cooled to $333 \mathrm{~K}$ $\left(60^{\circ} \mathrm{C}\right)$ and flows on the tube side. The make-up water addition to the tower is controlled by a float in the tower basin. The $\mathrm{pH}$ and conductivity are regulated with monitor units which operate appropriate valves at predetermined set points.

\subsection{Test Procedures}

The tube samples used were $183 \times 1.9 \mathrm{~cm}(6 \mathrm{ft} \times 3 / 4 \mathrm{in.})$ ASTM A-179 carbon steel tubing. The tubes were degreased, cleaned and prefilmed with the reagents indicated in Section 3.2. The tubes were visually inspected through a $1.9 \mathrm{~cm}$ plug in the heat exchanger after each step to ensure proper treatment, coupons inserted in the line were also removed for inspection. After preparing the tube samples the make-up water was added to the tower basin with chemical additives for scale and corrosion control. The chemical additives at one-fifth dosage were added to the make-up tanks to ensure control during the test. The make-up water used in these tests (unless stated otherwise) was geothermal water that had been treated chemically to reduce the silica concentration to $4 \mathrm{ppm} \mathrm{SiO}_{2}$ and hardness to $20 \mathrm{ppm} \mathrm{CaCO}_{3}$.

\subsection{Results and Discussion}

The pilot cooling tower tests evaluated a variety of scale and corrosion inhibitors, Table 1C, for carbon steel tubing exposed to aerated geothermal water. Most tests were of short duration due to copper deposition on tube surfaces and difficulty in establishing an adequate scale control treatment. 


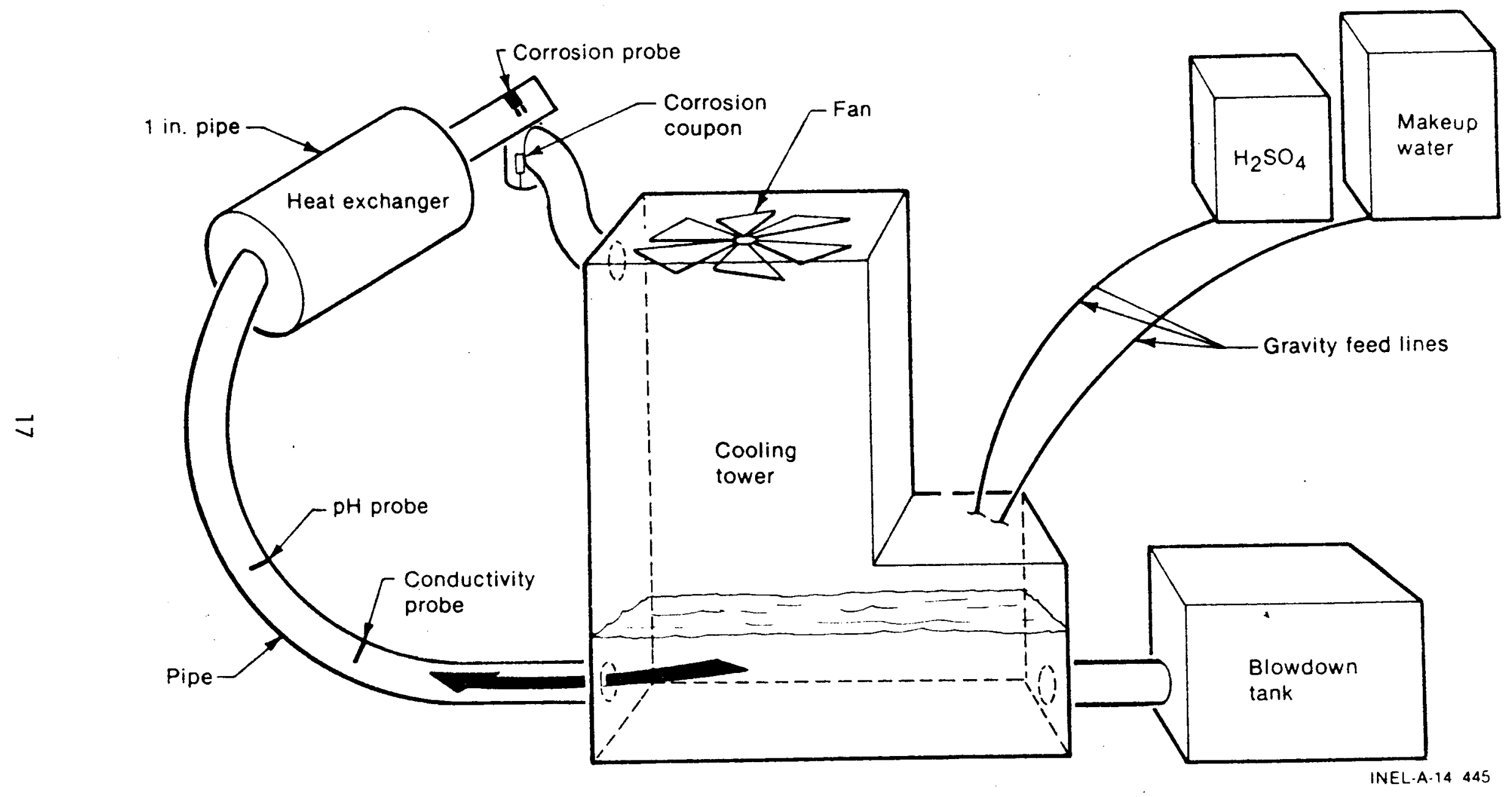

Figure 9: Pilot Cooling Tower Test Unit 
Tests 1 through 4 showed heavy copper deposits and the results were discarded with respect to corrosion as the presence of copper fons will accelerate the pitting of carbon steel. Tests 5 through 8 were run to evaluate various dispersants with a combination of Betz 2020 and 426 giving the best results.

Tests 9 and 10 compared scaling and corrosion tendencies of geothermal, domestic and reverse osmosis product waters. The results, as expected, show the lower the amount of chloride present the better the corrosion resistance. Test 11 ran high levels of polyphosphate resulting in a heavy phosphate scale. Tests 12 and 13 show that corrosion could be controlled with chromate, polyphosphate and zinc additives.

Tests 14 and 15 evaluate maximum phosphate concentrations that can be held in solution, type of phosphate and maximum zinc concentrations that can be maintained. Phosphate tended to deposit in the 55 to $60 \mathrm{ppm}$ total phosphate range and zinc in the 4 to $5 \mathrm{ppm}$ range, and the polyphosphate (35-A) appears to give better corrosion protection than the ortho phosphate (2040). Tests 16 and 17 were run to determine corrosion rates over a longer time period. Two short term tests were run evaluating two non Betz products but showed severe corrosion and scaling in the five days and hence were terminated.

Actual pit depths are given only for three tubes from Test 13. These tests were the only ones of significant length, i.e., 800 to 2300 hours. The pit depths of the other tube samples evaluated by Radian ${ }^{a}$ all varied from 26 to $57 \mathrm{~m}$. This compared with a prefilmed tube sample showing pit depths of 13 to $22 \mathrm{~m}$. This data correlates well with the spinner test results that indicate more corrosion occurs during the prefilming than in

a. The Radian reports consist of a series of letters written following their examination of each set of tube samples. 
the short time the sample is exposed. The data show that pitting corrosion has been significantly reduced, but longer term testing is required for statistical analysis to project time to first tube perforation.

\subsection{Conclusions and Recommendations}

Analysis of data from water treatment tests show that:

1. A chrome-zinc-phosphate inhibitor treatment system will provide adequate corrosion protection; adequate being defined as time required to retube, approximately 2-3 years.

2. A phosphate-zinc inhibitor treatment system has reduced pitting and may be adequate.

3. That scale deposition can be prevented by chemical pretreatment and use of dispersants.

In view of the high chemical operating costs associated with the use of spent brine and carbon steel tubing, it is recommended that corrosion studies be performed to determine materials for replacement of all carbon steel components in the water treatment system. Failure due to corrosion of some carbon steel components, water box, piping etc., is not a concern. However, dissolution of iron from these components will result in the deposition of iron silicate scale if silica exceeds $30 \mathrm{ppm}$. This will have a large economic impact on plant operating cost due to the increased chemical requirements of the pretreatment system for silica removal. 
1. Suciu, D. F. and Miller, R. L. Short-Term Pilot Cooling Tower Tests: EG\&G-FM-5087 January 1980.

2. A series of letters by the Radian Corporation under government contract number DCN $80-212-003-X$.

3. A. Wachter and R. S. Treseder: Planned Interval Test Method; Chem. Eng. Prog; 43: 315-326 (1947). 
$\theta$

APPENDIX A 
APPENDIX A

\section{Cleaning and Filming Tests}

The following tables summarize the tests that were run to define a chemical cleaning and passivating program for the $5 \mathrm{MW}(\mathrm{e})$ isobutane condenser.

The water used in all tests was Raft River domestic water heated to $333 \mathrm{~K}\left(60^{\circ} \mathrm{C}\right)$. The cleaning step in each test used doubled inhibited phosphoric acid for the $\mathrm{pH}$ adjustment.

The tubes from all tests were removed, dried and sent to the Radian corporation for analysis. 


\section{APPENDIX A}

\section{Chemical Additives}

The following is a list of chemicals used in the test program.

Na1prep 331

- phosphate corrosion inhibitor

Chromate

- added as sodium dichromate

$\mathrm{NaOH}$

- sodium hydroxide

TSP

- trisodium phosphate

SMP

- sodium metaphosphate

Soap

- commercial liquid detergent

$\mathrm{NaHCO}_{3}$

- sodium bicarbonate

Betz 35

- Polyphosphate corrosion inhibitor

Betz 2040

- Orthophosphate corrosion inhibitor

Betz 2020

- Scale dispersant

Betz 426

- Scale dispersant

Bertz 562-C, tta - Copper corrosion inhibitor

Zinc

- Corrosion inhibitor, added as zinc sulfate 
Test

Controls

filming

time $h r$

$\mathrm{pH}$

Na Tprep 331

Test

Filming time $\mathrm{hr}$

$\mathrm{pH}$

Chromate

Na Iprep 331

Test

Cleaning time $\mathrm{hr}$

$\mathrm{pH}$

Filming time $h r$

$\mathrm{pH}$

Na Iprep 331

Test

$\mathrm{Cl}$ eaning time $\mathrm{hr}$

$\mathrm{pH}$

Filming time $h r$

Chromate

Na Iprep 331

$\mathrm{pH}$

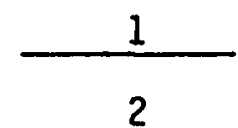

6.0

$12,500 \mathrm{ppm}$

5

8

6.0

$1,000 \mathrm{ppm}$

$50 \mathrm{ppm}$

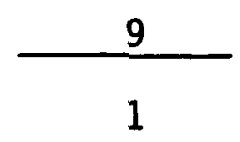

2.5

1.0

6.0

$12,500 \mathrm{ppm}$

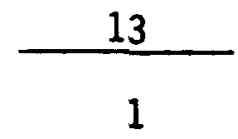

2.5

9

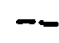

$12,500 \mathrm{ppm}$

6.1

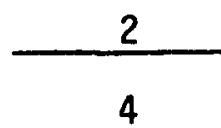

6.0

6.1

6.1

$12,500 \mathrm{ppm} \quad 12,500 \mathrm{ppm}$

$12,500 \mathrm{ppm}$
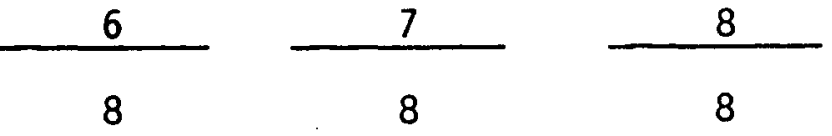

6.0

6.0

6.2

$1,000 \mathrm{ppm}$

$1,000 \mathrm{ppm}$

$1,000 \mathrm{ppm}$

$50 \mathrm{ppm}$

$50 \mathrm{ppm}$

$50 \mathrm{ppm}$

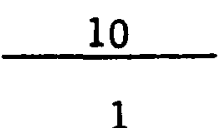

2.5

2.5

2.5

1.0

1.0

1.0

6.0

6.0

6.0

$12,500 \mathrm{ppm} \quad 12,500 \mathrm{ppm} \quad 12,500 \mathrm{ppm}$

14
1
2.5

9

9

$1,000 \mathrm{ppm}$

$50 \mathrm{ppm}$

6.0

6.0 
TABLE 1A. (continued)

\begin{tabular}{|c|c|c|c|c|}
\hline Test & 17 & 18 & 19 & 20 \\
\hline $\begin{array}{l}\text { Controls } \\
\text { Decreasing } \\
\text { time } h r\end{array}$ & 3 & 3 & 3 & 3 \\
\hline $\mathrm{NaOH}$ & $3 w / 0$ & $3 w / 0$ & $5 \mathrm{~W} / 0$ & $5 \mathrm{~W} / 0$ \\
\hline TSP & $1 \mathrm{~W} / 0$ & $1 W / 0$ & $5 \mathrm{~W} / 0$ & $1 \mathrm{w} / 0$ \\
\hline SMP & -- & $1 \mathrm{~W} / 0$ & $1 \mathrm{~W} / 0$ & -- \\
\hline Soap & 4 drops & 4 drops & 4 drops & 4 drops \\
\hline Cleaning time $\mathrm{hr}$ & 3 & 3 & 3 & 3 \\
\hline pH & 2.5 & 2.5 & 2.5 & 2.5 \\
\hline Neutralization & -- & -- & $1 \mathrm{hr}$ & 1 \\
\hline $\mathrm{NaHCO}_{3}$ & -- & -- & $0.3 \mathrm{~W} / 0$ & $0.3 \mathrm{w} / 0$ \\
\hline Time $h r$ & 4 & 6 & 4 & 6 \\
\hline $\mathrm{pH}$ & 6.5 & 6.5 & 6.5 & 6.5 \\
\hline Na 1 prep & $2,000 \mathrm{ppm}$ & $2,000 \mathrm{ppm}$ & $2,000 \mathrm{ppm}$ & $2,000 \mathrm{ppm}$ \\
\hline $\mathrm{Na}_{2} \mathrm{CrO}_{4}$ & $3,000 \mathrm{ppm}$ & $3,000 \mathrm{ppm}$ & $3,000 \mathrm{ppm}$ & $3,000 \mathrm{ppm}$ \\
\hline Test & 21 & 22 & 23 & 24 \\
\hline $\begin{array}{l}\text { Degreasing } \\
\text { time } h r\end{array}$ & 3 & 3 & 3 & 3 \\
\hline $\mathrm{NaOH}$ & $3 \mathrm{w} / 0$ & $3 \mathrm{~W} / 0$ & $5 \mathrm{~W} / 0$ & $5 \mathrm{~W} / 0$ \\
\hline TSP & $1 \mathrm{~W} / 0$ & $1 \mathrm{~W} / 0$ & $5 \mathrm{w} / 0$ & $5 \mathrm{w} / 0$ \\
\hline SMP & -- & $1 \mathrm{w} / 0$ & -- & $1 \mathrm{~W} / 0$ \\
\hline Soap & 4 drops & 4 drops & 4 drops & 4 drops \\
\hline Cleaning time $\mathrm{hr}$ & 3 & 3 & 3. & 3 \\
\hline $\mathrm{pH}$ & 2.5 & 2.5 & 2.5 & 2.5 \\
\hline Fi lming time $h r$ & 4 & 6 & 4 & 6 \\
\hline
\end{tabular}


TABLE 1A. (continued)

\begin{tabular}{|c|c|c|c|c|}
\hline $\mathrm{pH}$ & 6.5 & 6.5 & 6.5 & 6.5 \\
\hline Na lprep 331 & $12,500 \mathrm{ppm}$ & $12,500, \mathrm{ppm}$ & $12,500 \mathrm{ppm}$ & $12,500 \mathrm{ppm}$ \\
\hline Test & 25 & 26 & 27 & 28 \\
\hline $\begin{array}{l}\text { De greasing } \\
\text { time } h r\end{array}$ & 3 & 3 & 3 & 3 \\
\hline $\mathrm{NaOH}$ & $5 w / 0$ & $5 w / 0$ & $5 \mathrm{~W} / 0$ & $5 \mathrm{w} / 0$ \\
\hline TSP & $1 \mathrm{~W} / 0$ & $1 \mathrm{~W} / 0$ & $1 W / 0$ & $1 w / 0$ \\
\hline Cleaning time $\mathrm{hr}$ & 3 & 3 & 3 & 3 \\
\hline $\mathrm{pH}$ & 2.5 & 2.5 & 2.5 & 2.5 \\
\hline Filming time $h r$ & 4 & 6 & 4 & 6 \\
\hline $\mathrm{pH}$ & 6.5 & 6.5 & 6.5 & 6.5 \\
\hline Na lprep 331 & $12,500 \mathrm{ppm}$ & $12,500 \mathrm{ppm}$ & -- & -- \\
\hline $\mathrm{Na}_{2} \mathrm{CrO}_{4}$ & $1,400 \mathrm{ppm}$ & $1,400 \mathrm{ppm}$ & -- & -- \\
\hline $\mathrm{ZnCrO}_{4}$ & -- & -- & $3,000 \mathrm{ppm}$ & $3,000 \mathrm{ppm}$ \\
\hline Test & 29 & 30 & 31 & 32 \\
\hline $\begin{array}{l}\text { De gre asing } \\
\text { time } h r\end{array}$ & 3 & 3 & 3 & 3 \\
\hline $\mathrm{NaOH}$ & $5 \mathrm{~W} / 0$ & $5 \mathrm{~W} / 0$ & $5 w / 0$ & $5 \mathrm{~W} / 0$ \\
\hline TSP & $1 \mathrm{~W} / 0$ & $1 \mathrm{~W} / 0$ & $1 W / 0$ & $1 W / 0$ \\
\hline So ap & 4 drops & 4 drops & 4 drops & 4 drops \\
\hline Cleaning time $h r$ & 3 & 3 & 3 & 3 \\
\hline $\mathrm{pH}$ & 2.5 & 2.5 & 2.5 & 2.5 \\
\hline Filming time $\mathrm{hr}$ & 4 & 6 & 4 & 6 \\
\hline $\mathrm{pH}$ & 6.5 & 6.5 & 6.5 & 6.5 \\
\hline Na 1prep 331 & $30,000 \mathrm{ppm}$ & 30,000 ppm & 30,000 ppm & $30,000 \mathrm{ppm}$ \\
\hline $\mathrm{Na}_{2} \mathrm{CrO}_{4}$ & -- & -- & $1,400 \mathrm{ppm}$ & $1,400 \mathrm{ppm}$ \\
\hline
\end{tabular}


APPENDIX B

Spinner Test 
TABLE 1B. BASEL INE DATA

\begin{tabular}{|c|c|c|c|c|}
\hline Water & $\begin{array}{c}\text { Coupon } \\
\text { Condition } \\
\end{array}$ & $\mathrm{pH}$ & $\begin{array}{c}\text { Duration } \\
\text { (hr) } \\
\end{array}$ & $\begin{array}{l}\text { Weight Loss } \\
\frac{(g)}{}\end{array}$ \\
\hline Domestica & Prefilmed & 7.0 & 190 & 0.1367 \\
\hline Domestic & Unf ilmed & 7.0 & 190 & 0.3969 \\
\hline Tre atedb & Prefilmed & 7.0 & 190 & 1.9231 \\
\hline Treated & Unf $i 1$ med & 7.0 & 190 & 2.5702 \\
\hline
\end{tabular}

a. Raft River Domestic Well No. 2 .

b. Treated Geothermal Water.

TABLE 2B. CORROSION IN INEL TAP WATER

\begin{tabular}{|c|c|c|c|c|c|c|}
\hline $\begin{array}{l}\mathrm{CrO}_{4} \\
(\mathrm{ppm})\end{array}$ & $\begin{array}{c}\mathrm{PO}_{4} \\
(\mathrm{ppm}) \\
\end{array}$ & $\begin{array}{l}\mathrm{Cl}^{-} \\
\text {(ppm) } \\
\end{array}$ & $\mathrm{pH}$ & $\begin{array}{c}\text { Duration } \\
(\mathrm{hr} r) \\
\end{array}$ & $\begin{array}{l}\text { We ight Loss } \\
(\mathrm{g})\end{array}$ & $\begin{array}{l}\text { Max imum } \\
\text { Pit Depth } \\
(\mu \mathrm{m}) \\
\end{array}$ \\
\hline $100\left(\mathrm{ZnCrO}_{4}\right)$ & & 1000 & 6.5 & 163 & 0.0439 & 10 \\
\hline $100\left(\mathrm{ZnCrO}_{4}\right)$ & $10($ TSP $)$ & 1000 & 6.5 & 163 & 0.0313 & 18 \\
\hline \multirow[t]{2}{*}{$100\left(\mathrm{Na}_{2} \mathrm{Cr}_{2} \mathrm{O}_{7}\right)$} & 10 (TSP) & 1000 & 6.5 & 163 & 0.0532 & 30 \\
\hline & $100(T S P)$ & 1000 & 6.5 & 163 & 0.2012 & 146 \\
\hline
\end{tabular}




\begin{tabular}{|c|c|c|c|c|c|c|}
\hline $\begin{array}{l}\mathrm{CrO}_{4} \\
\text { (ppm) }\end{array}$ & $\begin{array}{c}\mathrm{PO}_{4} \\
\text { (ppm 35A) } \\
\end{array}$ & $\begin{array}{l}\mathrm{C1}^{-} \\
\text {(ppm) }\end{array}$ & $\mathrm{pH}$ & $\begin{array}{c}\text { Duration } \\
\text { (hr) }\end{array}$ & $\begin{array}{l}\text { We ight Loss } \\
\frac{(\mathrm{g})}{}\end{array}$ & $\begin{array}{l}\text { Maximum } \\
\text { Pit Depth } \\
(\mu \mathrm{m}) \\
\end{array}$ \\
\hline $100\left(\mathrm{ZnCrO}_{4}\right)$ & 90 & 5000 & 6.5 & 238 & 0.3031 & 22 \\
\hline $100\left(\mathrm{ZnCrO}_{4}\right)$ & & 5000 & 6.5 & 238 & 0.2261 & 20 \\
\hline \multirow[t]{2}{*}{$100\left(\mathrm{Na}_{2} \mathrm{Cr}_{2} \mathrm{O}_{7}\right)$} & 90 & 5000 & 6.5 & 238 & 0.2184 & 24 \\
\hline & 340 & 5000 & 6.5 & 238 & 0.4418 & \\
\hline
\end{tabular}

TABLE 4B. CORROSION AS A FUNCTION OF CHLORIDE CONCENTRATION WITH A CHROMATE INH IBI TOR SYSTEM

\begin{tabular}{|c|c|c|c|c|c|c|}
\hline $\begin{array}{l}\mathrm{Cl}^{-} \\
(\mathrm{ppm})\end{array}$ & $\mathrm{pH}$ & $\begin{array}{r}\mathrm{CrO}_{4} \\
(\mathrm{ppm}) \\
\end{array}$ & $\begin{array}{l}\mathrm{Zn} \\
(\mathrm{ppm})\end{array}$ & $\begin{array}{c}\mathrm{PO}_{4} \\
(\mathrm{ppm} 35 \mathrm{~A}) \\
\end{array}$ & $\begin{array}{c}\text { Duration } \\
\text { (hr) }\end{array}$ & $\begin{array}{l}\text { Maximum } \\
\text { Pit Depth } \\
(\mu \mathrm{m})\end{array}$ \\
\hline 1500 & 6.5 & 100 & 2 & 45 & 167 & 22 \\
\hline 3000 & 6.5 & 100 & 2 & 45 & 167 & 26 \\
\hline 10000 & 6.5 & 100 & 2 & 45 & 167 & 32 \\
\hline 15000 & 6.5 & 100 & 2 & 45 & 167 & 34 \\
\hline
\end{tabular}


TABLE 5B. CORROSION AS A FUNCTION OF CHLORIDE CONCENTRATION WITH A PHOSPHATE INH IBI TOR SYSTEM

\begin{tabular}{|c|c|c|c|c|c|}
\hline $\begin{array}{c}\mathrm{Cl} \\
(\mathrm{ppm})\end{array}$ & $\mathrm{pH}$ & $\begin{array}{c}\mathrm{PO}_{4} \\
\text { (ppm 2040) } \\
\end{array}$ & $\begin{array}{l}\text { Duration } \\
(\mathrm{hr}) \\
\end{array}$ & $\begin{array}{l}\text { We ight Loss } \\
\frac{(g)}{}\end{array}$ & $\begin{array}{l}\text { Maximum } \\
\text { Pit Depth } \\
(\mu \mathrm{m})\end{array}$ \\
\hline 1500 & $\overline{6.5}$ & 300 & 164 & 0.3055 & 20 \\
\hline 5000 & 6.5 & 300 & 164 & 0.3830 & 24 \\
\hline 15000 & 6.5 & 300 & 164 & 0.3793 & 30 \\
\hline
\end{tabular}

TABLE 6B. CORROSION AS A FUNCTION OF CHROMATE CONCENTRATION

\begin{tabular}{|c|c|c|c|c|c|c|}
\hline $\begin{array}{l}\mathrm{CrO}_{4} \\
(\mathrm{ppm})\end{array}$ & $\begin{array}{c}\mathrm{PO}_{4} \\
\text { (ppm 35A) } \\
\end{array}$ & $\begin{array}{l}\mathrm{Zn} \\
\text { (ppm) }\end{array}$ & $\mathrm{pH}$ & $\begin{array}{c}\text { Duration } \\
\text { (hr) }\end{array}$ & $\begin{array}{l}\text { We ight Loss } \\
(\mathrm{g})\end{array}$ & $\begin{array}{c}\text { Maximum } \\
\text { Pit Depth } \\
(\mu \mathrm{m}) \\
\end{array}$ \\
\hline 1000 & 85 & 2 & 6.5 & 163 & 0.3235 & 12 \\
\hline 5000 & 85 & 2 & 6.5 & 163 & 0.3419 & 16 \\
\hline 10000 & 85 & 2 & 6.5 & 163 & 0.3641 & 12 \\
\hline 15000 & 85 & 2 & 6.5 & 163 & 0.3898 & 16 \\
\hline
\end{tabular}


TABLE 7B. CORROSION AS A FUNCTION OF PH AND PHOSPHATE CONCENTRATION

\begin{tabular}{|c|c|c|c|c|c|}
\hline $\mathrm{pH}$ & $\begin{array}{c}\mathrm{PO}_{4} \\
\text { (ppm 35A) } \\
\end{array}$ & $\begin{array}{c}\mathrm{C1} \\
(\mathrm{ppm})\end{array}$ & $\begin{array}{c}\text { Duration } \\
(h r) \\
\end{array}$ & $\begin{array}{l}\text { We ight Loss } \\
\frac{(g)}{}\end{array}$ & $\begin{array}{c}\text { Maximum } \\
\text { Pit Depth } \\
(\mu \mathrm{m})\end{array}$ \\
\hline 6.5 & 22 & 1000 & 240 & 0.3825 & 22 \\
\hline 7.5 & 22 & 1000 & 240 & 0.3474 & 20 \\
\hline 6.5 & 44 & 1000 & 240 & 0.3932 & 16 \\
\hline 7.5 & 44 & 1000 & 240 & 0.2996 & 26 \\
\hline
\end{tabular}


APPENDIX C

PILOT COQ ING TOWER TESTS

The following tables summarize tests that were run as part of the Water Treatment program on the pilot cooling towers.

Al1 tubes used in these tests were degreased, acid cleaned and prefilmed prior to test startup. 
TEST 1

\begin{tabular}{|c|c|c|c|c|}
\hline Controls & Tower I & Tower II & Tower III & Tower IV \\
\hline Test Duration & 5 days & 5 days & 5 days & 5 days \\
\hline $\begin{array}{l}\text { Chromate Betz } 45 \\
\left(\mathrm{ZnCrO}_{4}\right)\end{array}$ & $100 \mathrm{ppm}$ & $100 \mathrm{ppm}$ & & \\
\hline Chromate $\left(\mathrm{NaCr}_{2} \mathrm{O}_{7}\right)$ & & $100 \mathrm{ppm}$ & & \\
\hline 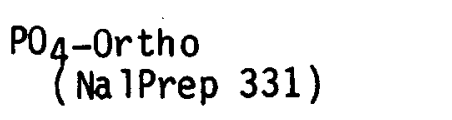 & & $15 \mathrm{ppm}$ & $15 \mathrm{ppm}$ & \\
\hline $\begin{array}{l}\mathrm{PO}_{4} \text {-Ortho } \\
\quad(\text { Betz 2040) }\end{array}$ & & & & $100 \mathrm{ppm}$ \\
\hline Betz 2020 & & & & $100 \mathrm{ppm}$ \\
\hline Betz Polysperse Plus & & & & $100 \mathrm{ppm}$ \\
\hline Betz 430 & $100 \mathrm{ppm}$ & $100 \mathrm{ppm}$ & $100 \mathrm{ppm}$ & \\
\hline pH & 6.5 & 6.5 & 6.5 & 6.5 \\
\hline Cycles & 5 & 5 & 5 & 5 \\
\hline
\end{tabular}

TEST 2

\begin{tabular}{|c|c|c|c|c|}
\hline Controls & Tower I & Tower II & Tower II I & Tower IV \\
\hline Test Duration & 6 days & 6 days & 6 days & 6 days \\
\hline Chromate & 100 ppm & 100 ppm & $100 \mathrm{ppm}$ & \\
\hline Na IPrep $311\left(\mathrm{PO}_{4}-0\right)$ & $15 \mathrm{ppm}$ & $15 \mathrm{ppm}$ & $15 \mathrm{ppm}$ & \\
\hline Betz 2040 & & & & $100 \mathrm{ppm}$ \\
\hline Betz 2020 & $100 \mathrm{ppm}$ & $100 \mathrm{ppm}$ & & $100 \mathrm{ppm}$ \\
\hline Betz Polysperse Plus & & $100 \mathrm{ppm}$ & & $100 \mathrm{ppm}$ \\
\hline Betz 426 & & & $50 \mathrm{ppm}$ & \\
\hline pH & 6.5 & 6.5 & 6.5 & 6.5 \\
\hline Cycles & 5 & 5 & 5 & 5 \\
\hline
\end{tabular}


TEST 3

\begin{tabular}{|c|c|c|c|c|}
\hline Controls & Tower I & Tower II & Tower III & Tower IV \\
\hline Test Duration & 4 days & 4 days & 4 days & 4 days \\
\hline Betz 45 & 100 ppm & & & \\
\hline Chromate & & $100 \mathrm{ppm}$ & & \\
\hline Na 1Prep 331 & & $15 \mathrm{ppm}$ & $60 \mathrm{ppm}$ & \\
\hline 2040 & & & & 100 ppm \\
\hline 2020 & & & & $100 \mathrm{ppm}$ \\
\hline 430 & $100 \mathrm{ppm}$ & 100 ppm & $100 \mathrm{ppm}$ & \\
\hline Polysperse Plus & & & & 200 ppm \\
\hline $\mathrm{pH}$ & 6.5 & 6.5 & 6.5 & 6.5 \\
\hline Cycles & 5 & 5 & 5 & 5 \\
\hline \multicolumn{5}{|l|}{ TEST 4} \\
\hline Controls & Tower I & Tower II & Tower III & Tower IV \\
\hline Test Duration & 5 days & 5 days & 5 days & 5 days \\
\hline Betz 45 & $100 \mathrm{ppm}$ & & & \\
\hline Chromate & & & $100 \mathrm{ppm}$ & \\
\hline Na IPrep 331 & & $15 \mathrm{ppm}$ & & \\
\hline 2040 & & & & 100 ppm \\
\hline 2020 & & 100 ppm & & 150 ppm \\
\hline 426 & & & $50 \mathrm{ppm}$ & \\
\hline 430 & 100 ppm & & & \\
\hline Polysperse Plus & & $100 \mathrm{ppm}$ & & 100 ppm \\
\hline pH & 6.5 & 6.5 & 6.5 & 6.5 \\
\hline Cycles & 5 & 5 & 5 & 5 \\
\hline
\end{tabular}


TEST 5

\begin{tabular}{|c|c|c|c|c|}
\hline Controls & Tower I & Tower II & Tower III & Tower IV \\
\hline Test Duration & 5 days & 5 days & 5 days & 5 days \\
\hline Chromate & 90 ppm & $100 \mathrm{ppm}$ & $100 \mathrm{ppm}$ & \\
\hline Na IPrep 331 & 22 ppm & $18 \mathrm{ppm}$ & 15 ppm & \\
\hline 2040 & & & & 100 ppm \\
\hline 2020 & 100 ppm & $100 \mathrm{ppm}$ & $100 \mathrm{ppm}$ & 100 ppm \\
\hline Polysperse Plus & 100 ppm & 100 ppm & & 100 ppm \\
\hline tta (copper inhibitor) & $5 \mathrm{ppm}$ & 5 ppm & $5 \mathrm{ppm}$ & 5 ppm \\
\hline $\mathrm{pH}$ & 6.5 & 6.5 & 6.5 & 6.5 \\
\hline Cycles & 5 & 5 & 5 & 5 \\
\hline \multicolumn{5}{|l|}{ TEST 6} \\
\hline Controls & Tower I & Tower II & Tower III & Tower IV \\
\hline Test Duration & 7 days & 7 days & 7 days & 7 days \\
\hline Chromate & & $100 \mathrm{ppm}$ & & \\
\hline Betz 45 & 50 ppm & & 100 ppm & 100 ppm \\
\hline 331 & $5 \mathrm{ppm}$ & & & 15 ppm \\
\hline 2020 & $200 \mathrm{ppm}$ & 200 ppm & & $200 \mathrm{ppm}$ \\
\hline Polysperse Plus & 200 ppm & 200 ppm & & \\
\hline 426 & & & 100 ppm & 100 ppm \\
\hline tta & $5 \mathrm{ppm}$ & $5 \mathrm{ppm}$ & $5 \mathrm{ppm}$ & 5 ppm \\
\hline $\mathrm{pH}$ & 6.5 & 6.5 & 6.5 & 6.5 \\
\hline Cycles & 5 & 5 & 5 & 5 \\
\hline
\end{tabular}


TEST 7

Controls Tower

14 days

300 p pm

5

200

2020

Polysperse Plus

426

tta

$\mathrm{pH}$

Cycles

TEST 8

Controls

Tower I

Tower II

Tower III

Tower IV

Test Duration

Chromate

Bet z 35-A

2020

426

tta

$\mathrm{pH}$

Cycles
5 days

$120 \mathrm{ppm}$

100 ppm

$250 \mathrm{ppm}$

$2 \mathrm{ppm}$

6.5

5
5 days

130 ppm

100 ppm

250 ppm

2 ppm

6.5

5
$100 \mathrm{ppm}$

$250 \mathrm{ppm}$

5 days

$120 \mathrm{ppm}$

$250 \mathrm{ppm}$

$2 \mathrm{ppm}$

6.5

5
14 days

150 ppm

25

200

200

2

6.5

5 Tower IV 
TEST 9

\begin{tabular}{|c|c|c|c|c|}
\hline Controls & Tower I & Tower II & Tower III & Tower IV \\
\hline Test Duration & 30 days & 30 days & 20 days & 12 days \\
\hline Water Source & Geothermal & Geothermal & Domestic & R.0. Product \\
\hline Chromate & 100 & 100 & 100 & 100 \\
\hline $\mathrm{Zn}$ & 4 & 4 & 4 & 4 \\
\hline $\mathrm{PO}_{4}-\mathrm{t}(35-\mathrm{A})$ & 31 & 37 & 44 & 43 \\
\hline 426 & 150 & 150 & 100 & 50 \\
\hline 2020 & 150 & 150 & 100 & 50 \\
\hline tta & 2 & 2 & 2 & 2 \\
\hline pH & 6.5 & 6.5 & 6.5 & 6.5 \\
\hline Cycles & 5 & 5 & 5 & 5 \\
\hline Comments & $\begin{array}{l}\text { Minor Scale } \\
\text { and Partial } \\
\text { Film Break- } \\
\text { down }\end{array}$ & $\begin{array}{l}\text { Minor Scale } \\
\text { and Partial } \\
\text { Film Break- } \\
\text { down }\end{array}$ & $\begin{array}{l}\text { Minor Scale } \\
\text { and Minor } \\
\text { Film Break- } \\
\text { down }\end{array}$ & $\begin{array}{l}\text { Scale Free } \\
\text { No Noticeable } \\
\text { Film Breaks }\end{array}$ \\
\hline
\end{tabular}


TEST 10

\begin{tabular}{|c|c|c|c|c|}
\hline Controls & Tower I & Tower II & Tower III & Tower IV \\
\hline Test Duration & Continued & Continued & Continued & 6 days \\
\hline Water & & & & Domestic \\
\hline Chromate & & & & 100 \\
\hline Zn & & & & 4 \\
\hline $\mathrm{PO}_{4}-\mathrm{t}(35-\mathrm{A})$ & & & & 35 \\
\hline 426 & & & & 100 \\
\hline 2020 & & & & 100 \\
\hline tta & & & & 2 \\
\hline $\mathrm{pH}$ & & & & 7.3 \\
\hline Cycles & & & & 5 \\
\hline Comments & & & & $\begin{array}{l}\text { Some Scale } \\
\text { and a Few } \\
\text { Observable } \\
\text { Pits }\end{array}$ \\
\hline
\end{tabular}


TEST 11

Controls Tower I Tower II Tower III Tower IV.

Test Duration Continued Continued 9 days 9 days

Water

Geothermal Geothermal

Chromate

$110 \quad 130$

$\mathrm{Zn}$

4

4

$\mathrm{PO}_{4}-\mathrm{t}$

65

65

2020

200

200

426

150

150

tta

8

7.5

8

$\mathrm{pH}$

5

7.5

Cycles

5

Comments

Large Scale No Film

Breakdown

Large Scale

Breakdown 
TEST 12

\begin{tabular}{|c|c|c|c|c|}
\hline Controls & Tower I & Tower II & Tower III & Tower IV \\
\hline Test Duration & 14 days & 14 days & 14 days & 14 days \\
\hline Water & Ge othermal & Ge othermal & Geothermal & Geothermal \\
\hline Chromate & 100 & 100 & 100 & \\
\hline $\mathrm{Zn}$ & 4 & 4 & 4 & 4 \\
\hline $\mathrm{PO}_{4}-\mathrm{t}(35-\mathrm{A})$ & 40 & & & \\
\hline 2040 & & 40 & & 150 \\
\hline 2020 & 150 & 150 & 150 & 150 \\
\hline 426 & 100 & 100 & 100 & 100 \\
\hline tta & 8 & 8 & 8 & 8 \\
\hline $\mathrm{pH}$ & 7.5 & 7.5 & 7.5 & 7.5 \\
\hline Cycles & 5 & 5 & 5 & 5 \\
\hline Comments & $\begin{array}{l}\text { Minor Scale } \\
\text { No Notice- } \\
\text { able Film } \\
\text { Breakdown }\end{array}$ & $\begin{array}{l}\text { Minor Scale } \\
\text { A Few Areas } \\
\text { of Film } \\
\text { Breakdown } \\
\text { and } \\
\text { Possible } \\
\text { Pits }\end{array}$ & $\begin{array}{l}\text { Minor Scale } \\
\text { Film Break- } \\
\text { down and } \\
\text { Pits }\end{array}$ & $\begin{array}{l}\text { Minor Scale } \\
\text { Small Amount } \\
\text { of Film } \\
\text { Breakdown, } \\
\text { but none that } \\
\text { could be } \\
\text { classified as } \\
\text { Pits }\end{array}$ \\
\hline
\end{tabular}




\begin{tabular}{|c|c|c|c|c|}
\hline Controls & Tower I & Tower II & Tower II I & Tower IV \\
\hline $\begin{array}{l}\text { Test } \\
\text { Duration }\end{array}$ & & 34 days & 48 days & 97 days \\
\hline Chromate & $100 \mathrm{ppm}$ & -- & 100 ppm & 100 ppm \\
\hline $\begin{array}{l}\mathrm{PO}_{4}-\mathrm{T} \\
(35-\mathrm{A})\end{array}$ & 40 ppm & 40 ppm & $30 \mathrm{ppm}$ & $30 \mathrm{ppm}$ \\
\hline 2020 & $150 \mathrm{ppm}$ & $150 \mathrm{ppm}$ & $150 \mathrm{ppm}$ & $150 \mathrm{ppm}$ \\
\hline 426 & 100 ppm & 100 ppm & 100 ppm & 100 ppm \\
\hline tta & $10 \mathrm{ppm}$ & 10 ppm & 10 ppm & 10 ppm \\
\hline Zinc & $3 \mathrm{ppm}$ & 3 ppm & 3 ppm & $3 \mathrm{ppm}$ \\
\hline $\mathrm{pH}$ & & $6.8-7.2$ & $6.8-7.2$ & $6.8-7.2$ \\
\hline Cycles & 5 & 5 & 8 & 5 \\
\hline Comments & $\begin{array}{l}\text { Tower used to } \\
\text { evaluate upset } \\
\text { conditions }\end{array}$ & $\begin{array}{l}\text { Minor scale } \\
\text { partial film } \\
\text { breakdown pit } \\
\text { depth ave } \\
31 \text { m }\end{array}$ & $\begin{array}{l}\text { No scale } \\
\text { partial film } \\
\text { breakdown pit } \\
\text { depth } 22-37 \text { m }\end{array}$ & $\begin{array}{l}\text { No scale } \\
\text { partial film } \\
\text { breakdown pit } \\
\text { depth } \\
24-39 \text { um }\end{array}$ \\
\hline
\end{tabular}




\begin{tabular}{|c|c|c|c|c|}
\hline Controls & Tower I & Tower II & Tower II I & Tower IV \\
\hline $\begin{array}{l}\text { Test } \\
\text { Duration }\end{array}$ & 10 days & 10 days & 10 days & 10 days \\
\hline $35-A$ & 40 ppm & 70 ppm & -- & -- \\
\hline 2040 & -- & -- & 75 ppm & 100 ppm \\
\hline 2020 & $150 \mathrm{ppm}$ & $150 \mathrm{ppm}$ & $150 \mathrm{ppm}$ & 150 ppm \\
\hline 426 & 100 ppm & 100 ppm & 100 ppm & 100 ppm \\
\hline tta & 10 ppm & 10 ppm & 10 ppm & 10 ppm \\
\hline Zinc & 3 ppm & 3 ppm & 3 ppm & $3 \mathrm{ppm}$ \\
\hline $\mathrm{pH}$ & $6.8-7.2$ & $6.8-7.2$ & $6.8-7.2$ & $6.8-7.2$ \\
\hline Cycles & 5 & 5 & 5 & 5 \\
\hline Comments & $\begin{array}{l}\text { Trace amount } \\
\text { of scale } \\
\text { partial film } \\
\text { breakdown }\end{array}$ & $\begin{array}{l}\text { Heavy scale on } \\
\text { tube surface }\end{array}$ & $\begin{array}{l}\text { Heavy scale on } \\
\text { tube surface }\end{array}$ & $\begin{array}{l}\text { Heavy scale on } \\
\text { tube surface }\end{array}$ \\
\hline
\end{tabular}




\begin{tabular}{|c|c|c|c|c|}
\hline Controls & Tower I & Tower II & Tower III & Tower IV \\
\hline $\begin{array}{l}\text { Test } \\
\text { Duration }\end{array}$ & 14 days & 14 days & 14 days & 14 days \\
\hline $35-A$ & 35 ppm & $35 \mathrm{ppm}$ & - & -- \\
\hline 2040 & -- & -- & 50 ppm & $50 \mathrm{ppm}$ \\
\hline 2020 & 150 ppm & $150 \mathrm{ppm}$ & $150 \mathrm{ppm}$ & $150 \mathrm{ppm}$ \\
\hline 426 & $100 \mathrm{ppm}$ & 100 ppm & $100 \mathrm{ppm}$ & 100 ppm \\
\hline tta & 10 ppm & 10 ppm & 10 ppm & $10 \mathrm{ppm}$ \\
\hline Zinc & 3 ppm & 10 ppm & $3 \mathrm{ppm}$ & 10 ppm \\
\hline $\mathrm{pH}$ & $6.8-7.2$ & $6.8-7.2$ & $6.8-7.2$ & $6.8-7.2$ \\
\hline Cycles & 5 & 5 & 5 & 5 \\
\hline Comments & $\begin{array}{l}\text { Trace amount } \\
\text { of scale, } \\
\text { partial film } \\
\text { breakdown } \\
\text { Pit depth } \\
13-52 \mathrm{um}\end{array}$ & $\begin{array}{l}\text { Heavy scale } \\
\text { zinc levels } \\
\text { cannot be } \\
\text { maintained at } \\
10 \text { ppm } \\
\text { Pit depth } \\
9-41 \text { m }\end{array}$ & $\begin{array}{l}\text { Trace amount } \\
\text { of scale, } \\
\text { partial film } \\
\text { breakdown } \\
\text { Pit depth } \\
76-126 \mu \mathrm{m}\end{array}$ & $\begin{array}{l}\text { Heavy scale } \\
\text { zinc levels } \\
\text { cannot be } \\
\text { maintained at } \\
10 \text { ppm } \\
\text { Pit depth } \\
58-74 \text { um }\end{array}$ \\
\hline
\end{tabular}




\begin{tabular}{|c|c|c|c|c|}
\hline Controls & Tower I & Tower II & Tower III & Tower IV \\
\hline $\begin{array}{l}\text { Test } \\
\text { duration }\end{array}$ & 5 days & 60 days & 5 days & 60 days \\
\hline $\begin{array}{l}\text { IPL }-160 \\
\text { UOP } \\
\text { product }\end{array}$ & $350 \mathrm{ppm}$ & -- & -- & -- \\
\hline $\begin{array}{l}\text { Monottes } \\
\text { plus } \\
\text { Du isdot } \\
\text { product }\end{array}$ & -- & -- & $350 \mathrm{ppm}$ & -- \\
\hline $35-A$ & -- & 40 ppm & -- & 40 ppm \\
\hline 2020 & -- & 150 ppm & -- & $150 \mathrm{ppm}$ \\
\hline 426 & -- & 100 ppm & -- & 100 ppm \\
\hline tta & -- & $10 \mathrm{ppm}$ & -- & $10 \mathrm{ppm}$ \\
\hline Zinc & -- & $3 \mathrm{ppm}$ & -- & 3 ppm \\
\hline pH & $6.8-7.2$ & $6.8-7.2$ & $6.8-7.2$ & $6.4-6.7$ \\
\hline Cycles & 5 & 5 & 5 & 5 \\
\hline Comments & $\begin{array}{l}\text { Severe } \\
\text { corrosion } \\
\text { water red and } \\
\text { oblique }\end{array}$ & $\begin{array}{l}\text { Pit depth } \\
48-59 \mu \mathrm{m} \\
\text { Minor scale }\end{array}$ & $\begin{array}{l}\text { Severe } \\
\text { corrosion } \\
\text { water red and } \\
\text { oblique }\end{array}$ & $\begin{array}{l}\text { Pit depth } \\
44-94 \text { um } \\
\text { Minor scale }\end{array}$ \\
\hline
\end{tabular}


IEST 17

\begin{tabular}{lcc}
\hline \multicolumn{1}{c}{ Controls } & \multicolumn{1}{c}{ Tower I } & \multicolumn{1}{c}{ Tower II I } \\
\cline { 2 - 3 } Test Duration & 53 days & 53 days \\
2040 & $50 \mathrm{ppm}$ & $50 \mathrm{ppm}$ \\
2020 & $150 \mathrm{ppm}$ & $150 \mathrm{ppm}$ \\
426 & $100 \mathrm{ppm}$ & $100 \mathrm{ppm}$ \\
tta & $10 \mathrm{ppm}$ & $10 \mathrm{ppm}$ \\
Zinc & $3 \mathrm{ppm}$ & $3 \mathrm{ppm}$ \\
pH & $6.8-7.2$ & $6.4-6.7$ \\
Cycles & 5 & 5 \\
Comments & Pit depth & Pit depth \\
& $44-54 \mu \mathrm{m}$ & $45-76 \mu \mathrm{m}$ \\
\hline
\end{tabular}

